\title{
Interpreting clinical assays for histone deacetylase inhibitors
}

\author{
This article was published in the following Dove Press journal: \\ Cancer Management and Research \\ 7 May 201I \\ Number of times this article has been viewed
}

\section{Nadine Martinet ${ }^{\prime}$ \\ Philippe Bertrand ${ }^{2}$ \\ 'Laboratory of Bioactive Molecules, Institute of Chemistry, University of Nice - Sophia Antipolis, Parc Valrose, Nice, France; ${ }^{2}$ Laboratory of Synthesis and Reactivity of Natural Substances, University of Poitiers, Poitiers, France}

Correspondence: Philippe Bertrand Laboratoire Synthèse et Réactivité des Substances Naturelles, UMR 65I 4 CNRS - Université de Poitiers, rue Jacques Fort, B28, 86022, Poitiers, France

Tel (33) 0549454 I 92

Fax (33) 0549453501

Email philippe.bertrand@univ-poitiers.fr

\begin{abstract}
As opposed to genetics, dealing with gene expressions by direct DNA sequence modifications, the term epigenetics applies to all the external influences that target the chromatin structure of cells with impact on gene expression unrelated to the sequence coding of DNA itself. In normal cells, epigenetics modulates gene expression through all development steps. When "imprinted" early by the environment, epigenetic changes influence the organism at an early stage and can be transmitted to the progeny. Together with DNA sequence alterations, DNA aberrant cytosine methylation and microRNA deregulation, epigenetic modifications participate in the malignant transformation of cells. Their reversible nature has led to the emergence of the promising field of epigenetic therapy. The efforts made to inhibit in particular the epigenetic enzyme family called histone deacetylases (HDACs) are described. HDAC inhibitors (HDACi) have been proposed as a viable clinical therapeutic approach for the treatment of leukemia and solid tumors, but also to a lesser degree for noncancerous diseases. Three epigenetic drugs are already arriving at the patient's bedside, and more than 100 clinical assays for HDACi are registered on the National Cancer Institute website. They explore the eventual additive benefits of combined therapies. In the context of the pleiotropic effects of HDAC isoforms, more specific HDACi and more informative screening tests are being developed for the benefit of the patients.
\end{abstract}

Keywords: histone deacetylase inhibitors, epigenetic, clinical trials interpretation

\section{Introduction}

The transcriptional state of a eukaryotic gene is determined by the surrounding chromatin architecture, the state of DNA cytosine methylation in the promoter/first exons and the associated regulating microRNAs (miRNAs).

In the cell nucleus, the genome is packaged into a superstructure, the chromatin, whose elementary dynamic units are the nucleosomes. Each is made up of four associated dimers of core histones (H2A, H2B, H3, and H4) around which 147 base pairs of DNA are wrapped, the nucleosomes being finally linked together via the linker histone H1 (Figure 1). Chromatin is compacted around the DNA into a so-called "closed state" when cells are resting. It is opened into an "active state" to allow for gene transcription by adenosine triphosphate (ATP)-dependent protein complexes, which remodel the chromatin architecture. Theses complexes modify the accessibility of DNA regulatory sites through both repositioning (sliding) and ejecting nucleosomes. Modeling complexes include transcription co-activators, transcription factors, and epi-enzymes. ${ }^{1}$ Histone acetyltransferases (HATs), for instance, acetylate specific lysine residues of histones and convert them into an amide form, loosening histone contacts with DNA, resulting in exposed binding sites for the transcription 


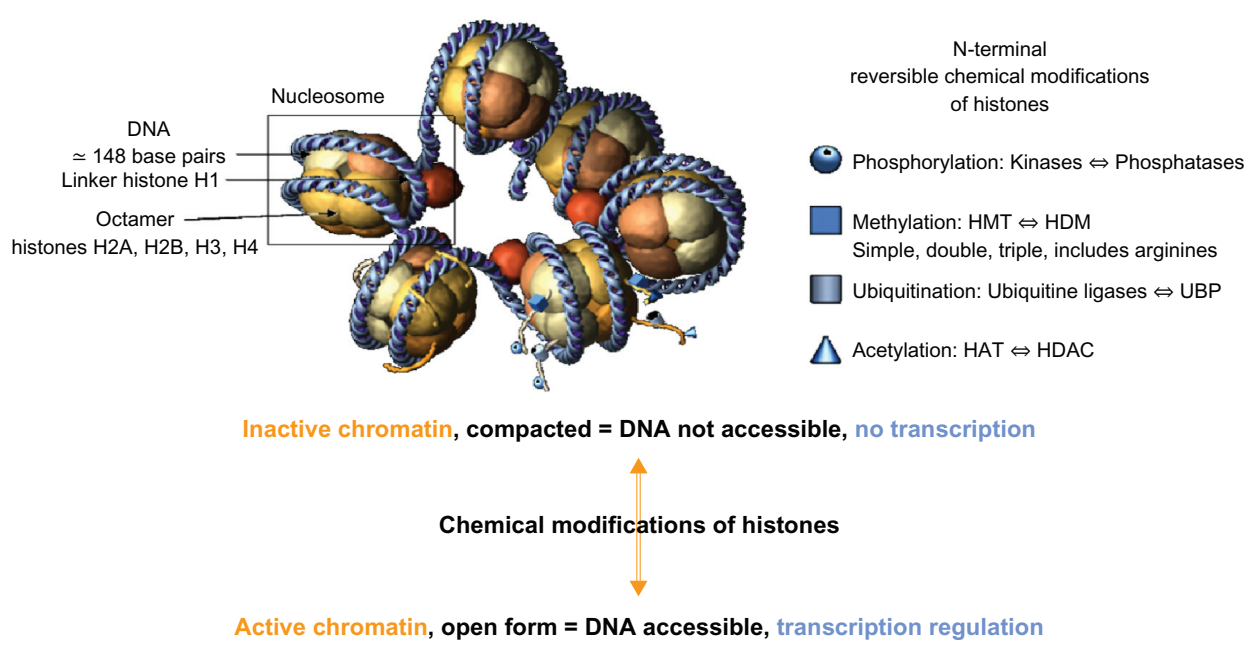

Figure I The nucleosome unit and the histone tail chemical modification.

Abbreviations: HAT, histone acetyltransferase; HDM, histone demethylases; HDAC, histone deacetylase; HMT, histone methyltransferase; UBP, ubiquitin-specific protease.

machinery. On the other hand, other complexes function as gene silencers and deny the same machinery access to DNA. Repressive complexes include histone deacetylases (HDACs), which deacetylate specific lysine residues of the histones tails to induce tighter interactions between the now positively charged lysine ( $\mathrm{N} \varepsilon$ protonated form) and the negatively-charged DNA phosphate groups. ${ }^{2}$ Beside acetylation, several other post-translational lysine modifications in histones have been described: methylation, phosphorylation, SUMOylation, and ATP-ribosylation. ${ }^{3,4}$

All the modifications incurred by histones form the "histone code". For example, K9 in $\mathrm{H} 3$ turns the chromatin into inactivity when methylated. Phosphorylation of serine 10 in the same $\mathrm{H} 3$ is required for methylation of $\mathrm{K} 4$ and acetylation of K9 and K14. Similar enzyme crosstalk has also been described, for ubiquitination of K120 in H2B prior to methylation of K79 in H3. Several epi-enzyme families are involved in the histones modifications. HATs and HDACs ${ }^{2}$ have balancing actions for histones acetylation. Methylation of histones ${ }^{6}$ is controlled by histones methyltransferases (HMTs) and histones demethylases (HDMs), while histones arginine methylation is catalyzed by the protein arginine $\mathrm{N}$-methyltransferases family of enzymes. ${ }^{7-9}$ One, two, or three methylations are possible, with impact on gene expression/repression. ${ }^{10}$ The analysis of epigenetic marks at the genome-wide scale has shown that monomethylated $\mathrm{H} 3 \mathrm{~K} 4$ is associated with transcription factors binding to enhancers, trimethylated $\mathrm{H} 3 \mathrm{~K} 4$ with transcription start sites, and dimethylated $\mathrm{H} 3 \mathrm{~K} 4$ with both transcription start sites and enhancers. ${ }^{11}$

DNA methyltransferases (DNMTs) repress gene expression via DNA cytosine methylation, unfavorable to transcription factor binding. DNMTs are recruited and stabilized, on
DNA, by HMTs and HDMs. Both are also able to recruit HDACs, methyl-binding proteins like methyl $\mathrm{CpG}$ binding protein 2 (MECP2), and several co-factors to further tune gene expression. ${ }^{12,13}$ Since DNMT co-factors are lacking in normal tissues, gene re-expression induced by DNMT inhibitors could be limited to tumor tissues to reduce "off-target" effects. DNA methylation in the epigenomes of human embryonic stem cells is an important field of research. The roles of DNA methylation in cancer genesis have also been extensively studied. ${ }^{12,13}$

Catalyzed by the ten-eleven translocation 1 (TET) family of enzymes, DNA hydroxymethylcytosine has been recently described as a step towards cytosine demethylation. ${ }^{14}$ Mutations and translocations of TET are present in myeloid malignancies. ${ }^{15}$ The role of hydroxymethylcytosine, if any, is not yet understood, but its existence questions all the results obtained so far when determining the cytosine methylation status.

In a further step of complexity, specialized miRNAs read the epi-code and target effectors genes to modulate their expression. MiRNAs are small non-coding RNAs of 20-22 nucleotides that inhibit gene expression when they engage either in imperfect base-pairing with their target mRNA $3^{\prime}$-untranslated region or affect its stability. MiRNA 29-a, -b and $-c$ target DNMT3a and b directly and cell-specifically. HDAC4 is targeted by both miR-1 and miR-140, while miR-449-a targets HDAC1 in prostate malignant cells. ${ }^{16}$ Onco-proteins like promyelocyte leukemia retinoic acid receptor- $\alpha$ (PML-RAR $\alpha$ ) in promyelocytic leukemia and B-cell lymphoma 6 in non-Hodgkin's lymphoma result from translocations. It is near the premiR-223 region that the $\mathrm{t}(8 ; 21)$ translocation juxtaposes the Runt-related transcription 
factor 1 gene on chromosome 21 with the Cytochrome B Termination 1 gene on chromosome 8 , generating the acute myeloid leukemia (AML)1-Eight Twenty One fusion gene. ${ }^{17}$ The recruitment, on this chimerical site, of DNMT, MeCP2, and HDAC1 repressor complexes, promotes leukemogenesis. Epi-miRNAs write their own epi-code when their cytosines are methylated. Downregulation of miR-124a induces an up regulation of its target, cyclin-dependent kinase 6 (CDK6), as well as phosphorylation of retinoblastoma, and contributes to the abnormal proliferation of acute lymphoblastic leukemia (ALL) cells both in vitro and in vivo.

Most epigenetic changes translate into either up regulation or silencing of gene expression. ${ }^{18}$ When inappropriate, they predispose the organism to more mutational events via increased genomic instability and aberrant cellular signaling. The field of epigenetic being extremely prolific, we have restricted our reference list to the essentials.

\section{HDACs}

HDACs remove the acetyl group from an $\mathrm{N}$ - $\varepsilon$-acetyl lysine located near the amino terminus of a core histone, cleaving an amide bond and increasing the positive charge of the histone. The removal of acetyl groups from the histones tails stabilizes nucleosomal DNA-histones interactions by its subsequent change in electrostatic charges. It is the basis for HDAC-mediated transcriptional repression via chromatin condensation. ${ }^{19}$ HDACs have been categorized into four classes. Class I HDACs (HDAC1, 2, 3, and 8) are nuclear proteins with ubiquitous expression involved in regulating cell proliferation. ${ }^{20}$ HDAC2 has been shown to suppress apoptosis in tumor cells not only via both the intrinsic/ mitochondrial and the extrinsic/death-receptor pathways, but also via mitotic failure and autophagic cell death, while HDAC3 is involved in bone structure and S-phase check point. ${ }^{21,22}$ Class II HDACs have a tissue-specific expression and can shuttle between the nucleus and the cytoplasm. They are divided into two subclasses: IIa with HDAC4, 5, 7, and 9. HDAC4 represses chondrocyte hypertrophy. HDAC7 functions in the down regulation and apoptosis of T-cells. ${ }^{20}$ HDAC9 is involved in cardiomyocyte differentiation. ${ }^{23}$ Class $\mathrm{IIb}$ includes HDAC10 and HDAC6. The latter contains two tandem catalytic domains: one is for histones deacetylation and the other for deacetylation of $\alpha$-tubulin. HDAC6 has also the capacity to bind directly to ubiquitinated proteins through an ubiquitin-binding domain, to target cargo proteins for subsequent processing. HDAC6-specific effects on cell motility and the proteasome are thought to be responsible for much of the toxicity of HDACs inhibitors (HDACi). HDAC 10 and 9 are required for chromosome homologous recombination. ${ }^{24}$ Class III HDACs include 7 different members of the sirtuin (SIRT) family. They are dependent on nicotinamine adenine dinucleotide (NAD+) to remove the acetyl group from lysine residues in histones and nonhistone substrates. Resveratrol from grapes and red wine is a SIRT1 activator. ${ }^{25}$ HDAC11 is the only member of Class IV.

Thus, it appears that HDAC activity depends on isoform types, sub cellular localization, association into multi-protein complexes and even post-translational modifications. HDACs are also able to deacetylate nonhistone proteins such as transcription factors, chaperone proteins and effectors of DNA repair, cell-signaling and metabolism. The ongoing concept is that deacetylation stabilizes these proteins. HDACs have different developmental functions, as shown by the different phenotypes obtained in knockout mice. ${ }^{26}$ Disruption of HDAC1 causes early embryonic lethality. HDAC2 knockout mice are viable but present fatal multiple cardiac defects. Germline HDAC3-deficiency causes embryonic lethality. HDAC3 conditional knockout mice gave severe deficits in membranous and endochondral bone formation. Germline deletion of HDAC4 causes premature ossification of the developing bones. HDAC6-deficiency slightly enhances trabecular bone formation. HDAC7 knockout gave vascular defects. HDAC8 is essential for neural crest progenitor cell differentiation and skull bone formation. HDAC9 knockout mice are viable at birth but have a myocardial hypertrophy.

\section{HDACs and their inhibitors}

In tumor cells, deletion of a single HDAC is not sufficient to induce cell death but leads to nuclear bridging and fragmentation, and 'in fine' to cell mitotic catastrophe. This suggests that inhibition of HDAC may be sufficient for anticancer activity and provides a rational incentive for the development of HDACi. ${ }^{27}$ In the 1970 s, seminal experiments showed that treatment of cells with the short-chain fatty acid $\mathrm{NaB}$ (sodium butyrate) caused hyperacetylation of histone octamers and led to the discovery of HDACs. ${ }^{28}$ The zinc-dependent HDACs of classes I, II, and IV are now known to have a common active site made of a tubular hydrophobic channel with a zinc atom $\left(\mathrm{Zn}^{2+}\right)$ at its end, forming the enzyme catalytic pocket. ${ }^{29}$ The acetyl part of the lysine substrate in histones/ proteins bind to the zinc atom while the protein four carbon lysine chains fits into the catalytic pocket, and deacetylation then follows. An HDACi is designed to block the HDAC catalytic activity. Several possibilities exist: irreversible or reversible binding to the enzyme catalytic site, competition 
with the enzymatic substrate, and deformation of the enzyme. Accordingly and as shown in Figure 2, the pharmacophore model for HDACi includes a zinc-binding group, competing somehow with the natural acetyl lysine substrate, a hydrophobic cap interacting with the external surface of the active site (generally aromatic) generating specificity, and a short linker connecting these two elements, which fits in the catalytic pocket. The zinc-binding groups can be a carboxylic acid in valproic acid (VPA), a hydroxamic acid in Vorinostat, benzamide in Entinostat, sulfhydryl in Romidepsin, ${ }^{30}$ and a ketone in Trapoxin. The linkers can be simple carbon chains, like in Vorinostat, or aromatic groups, like in Entinostat. HDACi in clinical trials are reported in Figure 3. Trichostatine (TSA) from Streptomyces hygroscopius was isolated as an antifungal antibiotic and was incidentally shown to have an anti-proliferative activity on murine leukemia cells. Further studies demonstrated that it was a pan-HDACi. The hydroxamate portion at the end of the molecule acts as a zinc-binding group. Because of toxic side effects, it is not used clinically but participates in the rational conception of HDACi via molecular modeling, as shown in Figure 2.

Besides its HDAC inhibition activity, Vorinostat (Figure 2, left), deriving from TSA, has a complex and not yet fully characterized activity leading to the accumulation of acetylated histones and non histone proteins. First generation HDACi are not selective except for a partial selectivity achieved ${ }^{31,32}$ in rare cases using bulk chemical groups to generate specific interactions with the external surface of the active site of the enzyme, like in tubacin. ${ }^{33}$ Sulfur-based zinc-binding groups also showed some selectivity in compounds like Largazole, a potent and selective HDACi for HDAC1 and 2. It is a densely functionalized macrocyclic peptide isolated from the

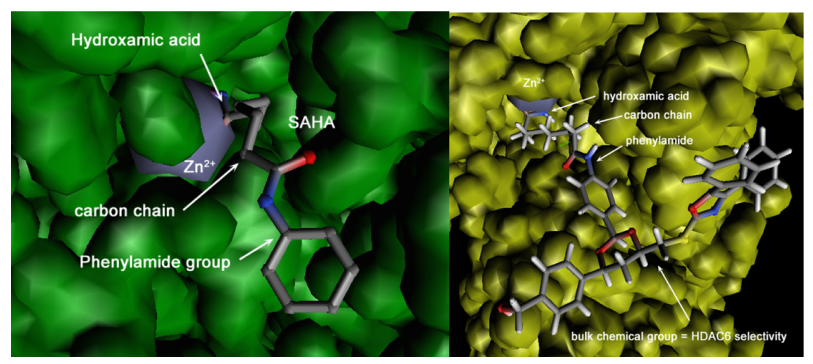

Figure 2 Left panel: X-ray crystallographic data for SAHA bound to HDAC8. The zinc atom in the HDAC active site is shown in grey. The hydroxamic acid group in SAHA is bound to $\mathrm{Zn}^{2+}$, the phenylamide group is outside the enzyme active site, and these two elements are linked by a short carbon chain. Right panel: Modeled tubulin bound to HDAC6. $\mathrm{Zn}^{2+}$ in the active site is shown in grey. The hydroxamic acid group in tubulin is bound to the $\mathrm{Zn}^{2+}$, the phenylamide group is outside the enzyme active site and these two elements are linked by a short carbon chain. A bulk chemical entity has been grafted onto the phenylamide part of SAHA to obtain selectivity towards HDAC6 due to specific S-pi interactions from sulfur atom (in yellow).

Abbreviations: HDAC, histone deacetylase; SAHA, suberoylanilide hydroxamicacid.
Cyanobacterium symploca $\mathrm{sp}$. by Luesch and coworkers. ${ }^{34}$ Entinostat and Mocetinostat have selectivity for HDAC1-3 and also against HDAC11 for the latter. Valproate and sodium butyrate $(\mathrm{NaB})$ better target HDAC I and IIa. For sirtuins $^{35}$ inhibition is based on $\mathrm{NAD}^{+}$competitive binding with attempts to propose a pharmacophore, according to the various inhibitor structures described. ${ }^{36}$

SIRT1 activation is the novel therapeutic approach to treat chronic inflammatory diseases, and enzyme activators are therefore sought. Many screening tests to search for HDACi use short histone peptides, capturing baits and engineered cells. All have their limitations because, in vivo, HDAC are parts of mega Daltons modeling chromatin complexes that may change within each cell type.

\section{HDAC inhibitors metabolism}

The metabolism of HDACi is an important concern during clinical assays. It is studied to determine the correlation between HDACi blood concentration, effective biological effects and eventual drug interactions. The known metabolisms of some HDACi are reported in Figure 4. TSA is metabolized as the inactive trichostatic acid, which is further demethylated ${ }^{37}$ for rapid clearance (Figure 4). Phenyl butyrate $(\mathrm{PB})$ metabolism has been described in several contexts. ${ }^{38} \mathrm{~PB}$ is $\beta$-oxidized to phenylacetate, and cleared out upon glutamine addition. Vorinostat is also oxidized to 4-anilino-4-oxobutanoic acid and glucuronylated. ${ }^{39,40}$ Romidepsin is a disulfide prodrug. The real active form corresponds to the free thiol metabolite, ${ }^{41}$ produced in vivo; the butenthiol part being thought to be the zinc-binding group. A glutathione conjugate has also been described, ${ }^{42}$ which is metabolized in vivo by the cytochrome $\mathrm{P} 450 \mathrm{~s}^{43}$ with slow and high acetylating subjects. Other HDACi stabilities have been investigated. ${ }^{44,45}$

\section{In-vitro effects of HDAC inhibitors}

DNA chips studied the transcriptome of cells treated with Vorinostat and Romidepsin, ${ }^{46}$ revealing that the expression of $40 \%$ of all genes was affected over a period of 16 hours. A Belinostat mRNA signature of 25 genes was sufficient to assess the overall gene modulation. Panobinostat modulated cell cycles and angiogenic genes. ${ }^{47}$ Tumor antigen expression modulation and major histo-compatibility antigen (MHC) molecule induction ${ }^{48}$ have been observed with Dacinostat. ${ }^{49}$ Mice bearing human tumor xenografts treated with Belinostat showed a modulation of the expression of genes active in the cellular G2/M phase. This was different from what was seen with 5-fluorouracil (5-FU), Cisplatin, Paclitaxel, or 


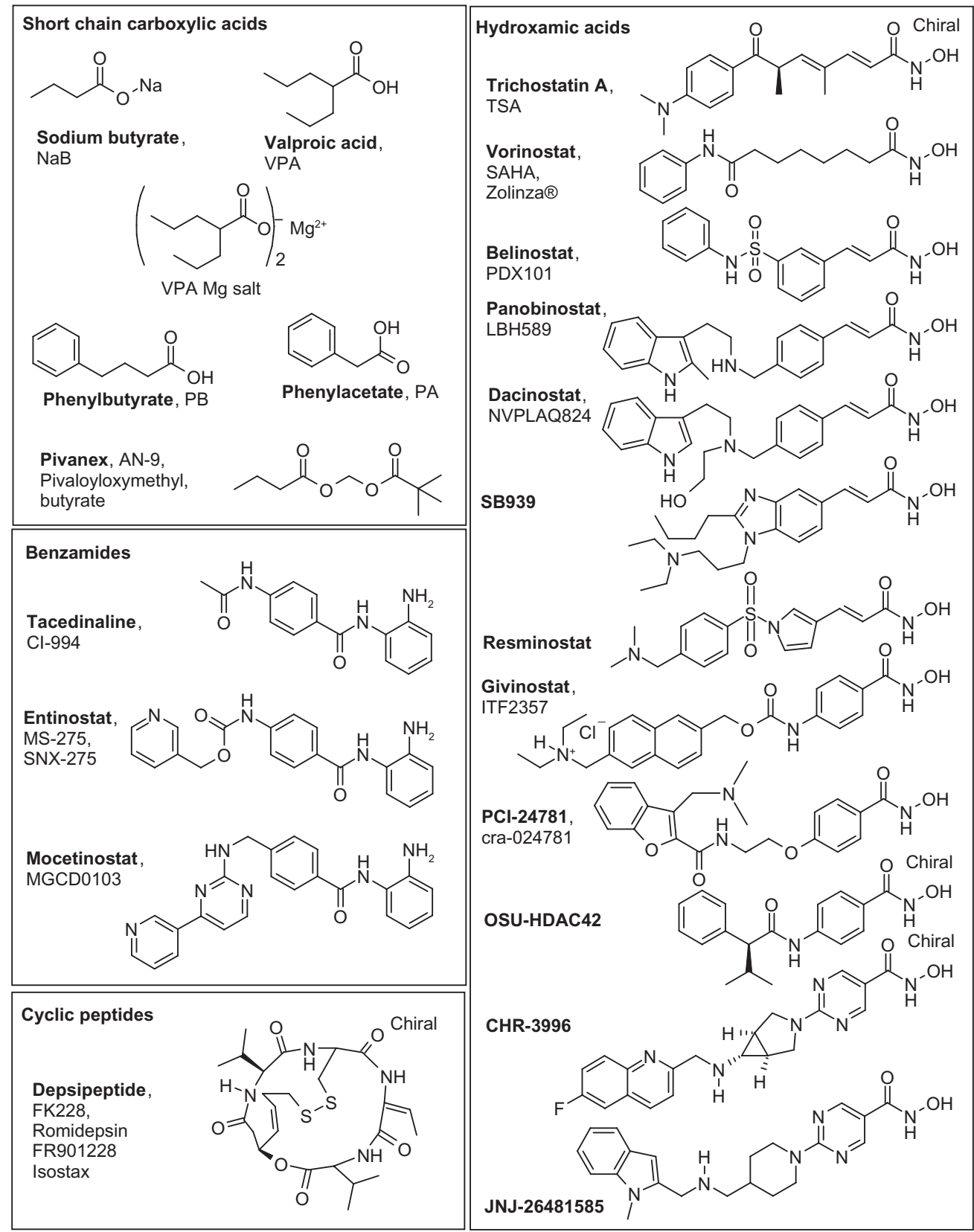

Figure 3 Histone deacetylase (HDAC) inhibitors used in clinical trials arranged by chemical classes.

Thiotepa. Synergistic effects were obtained when combining HDACi and DNA demethylating agents,,$^{50}$ or HDACi and all-trans retinoic acid (ATRA), a cell-differentiating agent used to treat acute promyelocytic leukemia (APL). ${ }^{51}$ The influence of epigenetic modulators to modify stem cell fate and its relevance for curing diseases has been reviewed. ${ }^{52}$ Successful therapeutic use of HDACi may thus depend on the cellular environment, the specific HDAC targeted, and the relative dependence of the tumor on the unique set of pathways influenced by a specific HDAC. Results are summarized in Table 1.53

\section{Clinical trials with zinc-dependent HDACi}

This part of the review describes the HDACi that have been or are being investigated in clinical trials. In Table 2 , all current trials are recapitulated. In Table 3, and for each molecule, some data related to epigenetic measurements are summarized.

\section{PB or its sodium salt}

$\mathrm{PB}$ or its corresponding sodium salt $(\mathrm{NaPB})$ is a short chain fatty acid approved by the Food and Drug Administration (FDA) for the treatment of hyperammonemia. It stops the 


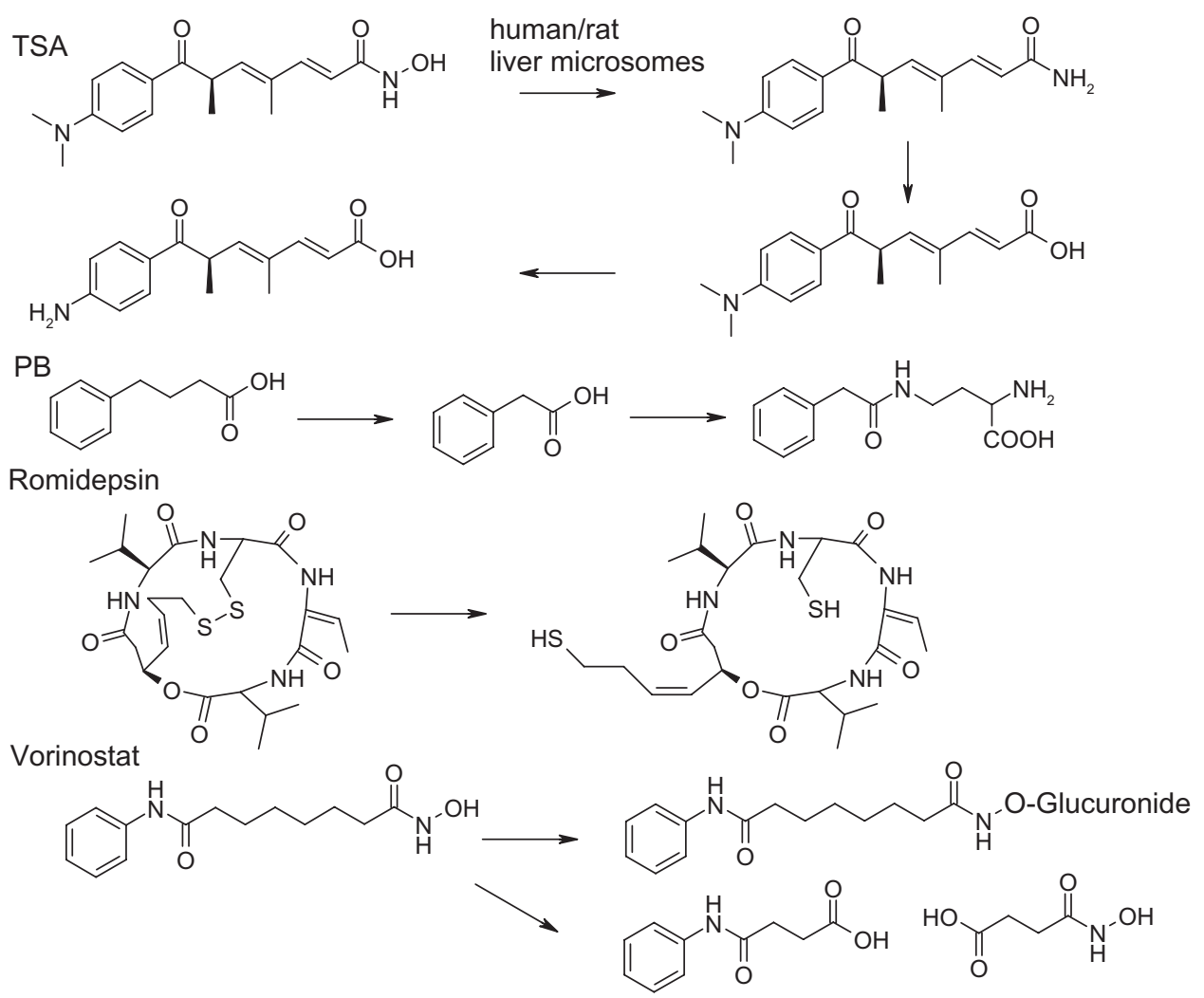

Figure 4 Metabolic processes for some histone deacetylase inhibitors. Abbreviations: PB, phenyl butyrate; TSA, trichostatin.

cell cycle in its G1-G0 phase. PB is an efficient HDACi at about $0.5 \mathrm{mM} .^{54,55} \mathrm{~PB}$ induces apoptosis - probably via c-jun N-terminal kinase (JNK) - in lung carcinoma cells, ${ }^{56}$ p21waf1-mediated growth arrest in MCF-7 cells, ${ }^{57}$ tumor necrosis factor $(\mathrm{TNF})-\alpha^{58}$ or peroxisome proliferator-activated receptor (PPAR) $\gamma$-mediated ${ }^{59}$ cell differentiation, and is more potent than phenylacetate in prostate cancer cells, ${ }^{60}$ while increasing MHC class I expression. $\mathrm{PB}$ is converted in vivo into the active metabolite phenylacetate (PA) by $\beta$-oxidation in the liver and kidney mitochondria ${ }^{61}$ Most dose-limiting toxicities (DLTs) are fatigue, nausea, and somnolence. Preliminary studies have been conducted in patients with recurrent glioblastoma multiform (GBM) ${ }^{62}$ (Table 3, A). Phase I studies have been conducted in patients with hormone refractory prostate cancers, ${ }^{63}$ refractory solid tumor malignancies ${ }^{64}$ like colon carcinoma, non small cell lung cancer (NSCLC), anaplastic astrocytoma, GBM, bladder carcinoma, sarcoma, ovarian carcinoma, rectal hemangiopericytoma, and pancreatic carcinoma ${ }^{65}$ mainly as intravenous infusions but also in AML and myelodysplastic syndrome (MDS). ${ }^{66}$ DLTs were neuro-cortical with milder fatigue and nausea/vomiting, light-headedness, short-term memory loss, sedation, confusion, and hypocalcemia. Although central nervous system
(CNS) toxicity was observed, infusions were well tolerated (Table 3, B). The active metabolite PA accumulated.

In the AML/MDS study ${ }^{67}$ with sequential administration of 5-aza-cytidine (5-aza) (Table 3, C), partial remissions or stable diseases were obtained. Targeting different biological mechanisms is feasible with acceptable toxicity. Phase I trials in combination with several drugs have been reported. Prostate, colorectal, leiomyosarcoma, and esophageal cancers were treated in combination with 5-aza (Table 3, C) ${ }^{68}$ metastatic colorectal cancer with fluorouracil 5-FU as a 24-hour continuous intravenous infusion (CIV). ${ }^{69}$ With 5-aza, no re-expression of E-cadherin, endothelin $\mathrm{B}$, and glutathione $\mathrm{S}$ transferase (GST) pi was observed, a result explained by the lack of dose effect or by the fact that DNA methylation is an S-phase-dependent process while in-vivo prostatic cells may be in S-phase at any given time. Stable disease was the best response. Combining 5-FU appeared also feasible.

\section{Pivaloyloxymethyl butyrate}

Pivaloyloxymethyl butyrate (AN)-9, is an ester prodrug of butyric acid $(\mathrm{BA})^{70}$ but with a greater potency at inducing malignant cell differentiation and tumor growth inhibition. It showed more favorable toxicological, pharmacological, 
Table I In-vitro modulation of gene expression by HDACi

\begin{tabular}{lll}
\hline HDACi & Gene expression & \\
\cline { 2 - 3 } & Upregulated (cell type) & Downregulated (cell type) \\
\hline $\begin{array}{l}\text { Vorinostat } \\
\text { Romidepsin }\end{array}$ & $\begin{array}{l}\text { TOBI, BTGI, BTG2, MXII, MAD, MLX, TIEG, ID2, ID3, } \\
\text { Vorinostat (in CDK2 } \\
\text { expressing cells) }\end{array}$ & MYC, MCM-3, MCM-5, MCM-7. \\
Belinostat & PKCA, PAKI, TRAFI. & ZAK, BCL2, B-MYC, GRIMI9, PDC4, P2RXI, \\
Panobinostat & CTGF, DHRS2, DNAJBI, HIF0, MAPI LC3B, ODC, SAT, & CD27. \\
& TACCI. & ABLI, CTPS, EIF4G2, KPNBI, CAD, RAN, TP53, \\
Apicidin & & P-FLT-3, FLT-3, Bcr-AbI, P-AKT, phospho-ERKI/2. \\
\hline
\end{tabular}

Abbreviations: TOBI, transducer of ERBB2; BTGI, B-cell translocation gene I; BTG2, B-cell translocation gene 2; MXII, MAX dimerization protein I; MAD, mitotic arrest deficient-like; MLX, MAX-like protein X; TIEG, Kruppel-like factor I0; ID2, inhibitor of DNA binding 2; ID3, inhibitor of DNA binding 3; CDKs, cyclin-dependent kinase; DRAKI, serine/threonine kinase; DRAK2, serine/threonine kinase I7b; DAPK3, death-associated protein kinase 3; GADD45 $\beta$, growth arrest and DNA-damage-inducible 45 beta; GADDI53, DNA-damage-inducible transcript 3; MYC, v-myc myelocytomatosis viral oncogene homolog tumor necrosis factor; MCM-3-7, minichromosome maintenance complex component 3-5-7; PRKCA, Protein kinase C a; PAKI, p2I protein (Cdc42/Rac)-activated kinase I; TRAFI, TNF receptor-associated factor I; ZAK, zinc finger protein 33A; BCL2, B-cell CLL/lymphoma 2; B-MYC, c-myc binding protein; GRIMI9, NADH dehydrogenase I alpha subcomplex; PDC4, DEP domain containing 4; P2RXI, purinergic receptor; P2X, ligand-gated ion channel I; D27, CD27 molecule; CTGF, connective tissue growth factor; DHRS2, dehydrogenase/reductase S2; DNAJBI, Dnal (Hsp40) homolog; subfamily B; member I; HIF0, HI histone family; member 0; MAPILC3B, microtubule-associated protein I light chain 3 beta; ODC, ornithine decarboxylase I; SAT, spermidine/spermine NI-acetyltransferase I; TACCI, transforming acidic coiled-coil containing protein I; ABLI, c-abl oncogene I; CTPS, CTP synthase; EIF4G2, eukaryotic translation initiation factor 4 gamma; KPNBI, karyopherin beta; CAD, carbamoyl-phosphate synthetase 2; RAN, member RAS oncogene family; TP53, tumor protein P53; TYMS, thymidylate synthetase; TD-60, regulator of chromosome condensation 2; FLT-3, fms-related tyrosine kinase 3; Bcr-Abl, c-abl oncogene I; non-receptor tyrosine kinase; p-AKT, v-akt murine thymoma viral oncogene homolog I; TS, Thymidilate synthase; CDKNIA, cyclin-dependent kinase inhibitor IA; CDK2, cyclin-dependent kinase inhibitor $2 \mathrm{~A}$.

and pharmaceutical properties than BA in preclinical studies. BA itself induces p16 expression and growth arrest of colon cancer cells, ${ }^{71}$ and modifies caspase distribution during apoptosis. $^{72}$ AN-9 down regulates c-jun and c-myc and induces differentiation in leukemia cells. ${ }^{73}$ It is decomposed by esterases in vivo to yield butyric and pivaloyl acids and a formaldehyde molecule, responsible for toxicity resulting in visual acuity disorders. It has demonstrated a synergistic effect with other anticancer agents by reducing bcl-2 levels. ${ }^{74}$ Initial study ${ }^{75}$ with I.V. of AN-9 in advanced solid malignancies (Table 3, E) gave partial responses, and stable diseases as best responses. Later, a multicenter trial of pivaloyloxymethyl butyrate $^{76}$ in refractory NSCLC (Table 3, F), administered as a continuous I.V. infusion, gave partial responses.

\section{VPA}

VPA is a nontoxic short-chain carboxylic acid used for the treatment of epilepsy with a long clinical history and well known pharmacokinetics (PKs) and pharmacodynamics (PDs). ${ }^{77,78}$ VPA induces chromatin decondensation, ${ }^{79}$ and differentiation in neural progenitor cells, ${ }^{80}$ and inhibits HDAC activity $^{81}$ in the $\mathrm{mM}$ range (preferentially HDAC1, 2). ${ }^{82}$ The antiproliferative activity was associated with aberrant cyclin D3 functionality during the C6 glioma G1 phase. ${ }^{83}$ Activation of PPAR $\delta$ was present in F9 cells. ${ }^{84}$ VPA induces caspase-dependent and -independent apoptosis in leukemia cells, ${ }^{85}$ and in AML cells expressing P-gp and multidrug resistance protein 1 (MRP1), ${ }^{86}$ inhibits production of TNF- $\alpha$ and interleukin (IL)-6 and activates nuclear factor kappa B $(\mathrm{NF}-\kappa \mathrm{B}) .{ }^{87} \mathrm{VPA}$ has been evaluated in combination with other anticancer compounds. For AML, increased 5-aza cytotoxicity was associated to cyclin D1 and p27(Kip1) expression, ${ }^{88}$ while sequential VPA/ATRA treatment reprograms differentiation. ${ }^{89} \mathrm{VPA}$ induces p16INK4A upregulation and apoptosis and sensitizes melanoma cells to chemotherapy. ${ }^{90}$ Interestingly, most of the clinical trials reported are for combination therapies.

A Phase I was conducted ${ }^{91}$ for refractory advanced cancer (colorectal, melanoma, NSCLC, and others) (Table 3, G). VPA/ATRA combination was evaluated for several diseases. Poor risk $\mathrm{AML}^{92}$ (Table 3, H), MDS and relapsed or refractory $\mathrm{AML}^{93}$ (Table 3, I) have also been investigated. A 52\% response rate was observed in MDS patients. ATRA exerted no additional effect in patients receiving the combination, but could be used to induce a second response in relapsing VPA-treated patients. In recurrent or refractory AML or MDS in a Phase II protocol ${ }^{94}$ (Table 3, J), ATRA was administered when VPA reached the target serum concentration. The differentiation therapy with VPA was effective in $30 \%$ of patients. In 11 elderly patients, de novo $\mathrm{AML}^{95}$ (Table 3, K) was also treated with theophyllin to increase cAMP levels and major cell differentiation. ${ }^{96}$ Complete marrow response was observed in three patients, including one complete remission. Two additional patients had hematologic improvement. Patients with AML-M6 were found particularly ${ }^{97}$ responsive, probably due to T-cell acute lymphocytic leukemia 1 
Table 2 Clinical trials for epigenetic drugs

Safety study of CHR-3996, in patients with advanced solid tumours

Safety and Tolerability of CHR-2845 to treat hematological diseases or lymphoid malignancies

A safety and dose-finding study of JNJ-2648I 585 for patients with advanced refractory leukemia or myelodysplastic syndrome

Phase II study of Givinostat in very high-risk relapsed/refractory Hodgkin's lymphoma patients

Phase II study of Givinostat followed by Mechlorethamine in relapsed/refractory Hodgkin's lymphoma patients

Phase II study of Givinostat in refractory/relapsed lymphocytic leukemia

Phase II study of Givinostat in combination with hydroxyurea in polycythemia vera

Clinical trial of Belinostat in patients with advanced multiple myeloma

Belinostat to treat tumors of the thymus at an advanced stage

Belinostat in relapsed or refractory peripheral T-cell lymphoma

Belinostat in treating patients with MSD

Safety and efficacy of Belinostat when used with standard of care chemotherapy for untreated NSCLC

A Phase I study of Belinostat in combination with Cisplatin and Etoposide in adults with SCLC and other advanced cancers

Vorinostat for locally advanced NSCLC

Vorinostat in treating patients with metastatic and/or locally advanced or locally recurrent thyroid cancer

A Study of the efficacy of Vorinostat in patients with polycythemia verae and essential thrombocythemia

Study of Vorinostat Plus Capecitabine and Cisplatin for Ist Line Treatment of metastatic or recurrent gastric cancer

Vorinostat with Capecitabine Using a new weekly dose regimen for advanced breast cancer

Study of Vorinostat combination with Bortezomib in patients with multiple myeloma

Study of Vorinostat and Gefitinib in relapsed/or refractory patients with advanced NSCLC

Proteasome Inhibitor NPI-0052 (marizomlib, salinosporamide A) and Vorinostat in patients with NSCLC, pancreatic cancer, melanoma or lymphoma Vorinostat combined with Gemtuzumab Ozogamicin, Idarubicin and Cytarabine in acute myeloid leukemia

Trial for locally advanced Her2 positive breast cancer using Vorinostat and Paclitaxel, Trastuzumab, Doxorubicin and Cyclophasmide on a weekly basis Sirolimus and Vorinostat in advanced cancer

Temsirolimus and Vorinostat in treating patients with metastatic prostate cancer

Vorinostat, Carboplatin and Gemcitabine plus Vorinostat maintenance in women with recurrent, Platinum-sensitive epithelial ovarian, Fallopian tube, or peritoneal cancer

Vorinostat and Gemcitabine in treating patients with metastatic or unresectable solid tumors

Vorinostat and Lenalidomide in treating patients with relapsed or refractory Hodgkin lymphoma or non-Hodgkin lymphoma

Hydroxychloroquine + Vorinostat in advanced solid tumors

Vorinostat in combination with palliative radiotherapy for patients with NSCLC

Vorinostat in combination with radiation therapy and infusional Fluorouracil (5-FU) in patients with locally advanced adenocarcinoma of the pancreas

Study of 5-azacytidine in combination with Vorinostat in patients with relapsed or refractory diffuse large B cell lymphoma

An Investigational Study of Vorinostat Plus Targretin (Bexaroten) in cutaneous T-cell lymphoma patients

Phase II Trial of Vorinostat and Tamoxifen for patients with breast cancer

Oral Panobinostat in relapsed or refractory CLL and MCL (non-Hodgkin's lymphoma)

Panobinostat in Phase II in SCLC

Panobinostat in treating patients with relapsed or refractory acute lymphoblastic leukemia or acute myeloid leukemia

Study of Oral Panobinostat in adult patients with refractory/resistant cutaneous T-cell lymphoma

Study of Bortezomib and Panobinostat in treating patients with relapsed/refractory peripheral T-cell lymphoma or NK/T-cell Lymphoma

Study of Panobinostat to treat malignant brain tumors

Study of Oral Panobinostat in patients with cutaneous T-cell lymphoma and adult T-cell leukemia/lymphoma

Panobinostat in adult patients with advanced solid tumors or cutaneous T-cell lymphoma

A study of Panobinostat as second-line therapy in patients with chronic graft-versus-host disease

Panobinostat treatment for refractory clear cell renal carcinoma

A Study to investigate the effect of food on oral Panobinostat absorption in patients with advanced solid tumors

ERB-B4 after treatment with Panobinostat in ER+ Tamoxifen refractory breast cancer

Panobinostat in addition to corticosteroids in patients with acute graft versus host disease

Panobinostat and Imatinib Mesylate in treating patients with previously treated chronic phase chronic myelogenous leukemia

Study of Imatinib, a Platelet-derived Growth Factor Receptor Inhibitor, and Panobinostat, in the treatment of newly diagnosed and recurrent chordoma

Oral Panobinostat in combination with Carboplatin and Paclitaxel in advanced solid tumors

Safety and efficacy studies of Panobinostat and Bicalutamide in patients with recurrent prostate cancer after castration

Panobinostat and Everolimus in treating patients with recurrent multiple myeloma, non-Hodgkin lymphoma, or Hodgkin lymphoma

Panobinostat and Fluorouracil followed by Leucovorin Calcium in treating patients with stage IV colorectal cancer who did not respond to previous

Fluorouracil-based chemotherapy

Sorafenib and Panobinostat in hepatocellular carcinoma

A Safety study of Panobinostat and Everolimus to stabilize kidney cancer

Phase I/II Study of Panobinostat and Erlotinib for advanced aerodigestive tract cancers

(Continued) 
Table 2 (Continued)

Use of Panobinostat with or without Rituximab to treat B-cell non-Hodgkin lymphoma

Entinostat in treating patients with advanced solid tumors or lymphoma

Entinostat in treating patients with hematologic cancer

Safety and efficacy study of Entinostat a new chemotherapy agent to treat metastatic melanoma

Entinostat and Sorafenib Tosylate in treating patients with advanced or metastatic solid tumors or refractory or relapsed acute myeloid leukemia

Entinostat and Isotretinoin in treating patients with metastatic or advanced solid tumors or lymphoma

Entinostat and Azacitidine in treating patients with myelodysplastic syndromes, chronic myelomonocytic leukemia, or acute myeloid leukemia

Entinostat and Clofarabine in treating patients with newly diagnosed, relapsed, or refractory poor-risk acute lymphoblastic leukemia or bilineage/

biphenotypic leukemia

A Phase II Study of Entinostat, in combination with GM-CSF treating relapsed and refractory myeloid malignancies

Azacitidine with or without Entinostat in treating patients with MSD, chronic myelomonocytic leukemia, or acute myeloid leukemia

Interleukin 2, Aldesleukin and Entinostat for kidney cancer

Safety and Efficiency Study of Valproic Acid In HAM/TSP

Valproic Acid as an effective therapy for chronic lymphocytic leukemia

Valproic Acid and Its effects on HIV latent reservoirs

Valproic Acid in treating patients with previously treated non-Hodgkin lymphoma, Hodgkin lymphoma, or chronic lymphocytic Leukemia

Bevacizumab, chemotherapy and Valproic Acid in advanced sarcoma

Combined therapy with Valproic Acid, All-trans Retinoic Acid (ATRA) and Cytarabine in acute myelogenous leukemia

Valproic Acid with Temozolomide and radiation therapy to treat brain tumors

Azacytidine and Valproic Acid in patients with advanced cancers

Phase II study of 5-Azacytidine Plus Valproic Acid and eventually ATRA in intermediate II and high risk MDS

Phase I/II Trial of Valproic Acid and Karenitecin for melanoma

5-azacytidine, Valproic Acid and ATRA in acute myeloid leukemia and high risk MDS

Hydralazine and Valproate added to chemotherapy for breast cancer

Hydralazine and Valproate plus Cisplatin chemoradiation in cervical cancer

A Pilot study of Pivanex in patients with chronic lymphocytic leukemia

A Pilot study of Pivanex in patients with malignant melanoma

Comparative trial of Pivanex and Docetaxel vs Docetaxel Monotherapy in Patients with advanced NSCLC

Study of SB939 in Subjects with myelofibrosis

SB939 in treating patients with locally advanced or metastatic solid tumors

SB939 in treating patients with recurrent or metastatic prostate cancer

Phase 2 study of Azacitidine vs MGCD0103 vs combination in elderly subjects with newly diagnosed AML or MDS

AR-42 (OSU-HDAC42) in treating patients with advanced or relapsed multiple myeloma, chronic lymphocytic leukemia, or Lymphoma

Resminostat in relapsed or refractory Hodgkin's lymphoma

Study of the safety and tolerability of PCl-2478 in patients with lymphoma

Safety and tolerability study of $\mathrm{PCl}-2478 \mathrm{I}$ in subjects with cancer

Phase I Study of gene induction mediated by sequential Decitabine/Depsipeptide infusion with or without concurrent Celecoxib in subjects with

pulmonary and pleural malignancies

Romidepsin in treating patients with relapsed or refractory non-Hodgkin's Lymphoma

Data from US National Cancer Institute

$(\mathrm{TAL} 1)^{98}$ and GATA $1^{99}$ interactions with HDACi, inducing differentiation in murine erythroleukemia (MEL) cells. Siitonen et al $^{100}$ reported a negative study trying VPA, in combination with 13-cis-retinoic acid (13-cis-RA) ${ }^{101}$ and 1,25-dihydroxyvitamin D3, in 19 naive patients with MDS or chronic myelomonocytic leukemia (CMML) (Table 3, L). Combinations with demethylating agents have been reported. Phase I/II ${ }^{102}$ study with 5-aza-2'-deoxycytidine (5-azaDc) in leukemia (Table 3, M) included gene expression analysis (p57kip2, p15, p73, MDR1 and THBS2). Initial DNMT1 levels were too low to be informative. A Phase I study ${ }^{103}$ with 5-azaDc in AML (Table 3, N) gave partial to complete remissions, warranting further studies of 5-azaDc alone or with alternative HDACi. A Phase $\mathrm{I}^{104}$ study of epigenetic modulation with 5-aza for advanced cancers (Table 3, O, colon, skin melanoma, breast, other) gave stable diseases. A Phase I/II study ${ }^{105}$ with 5-aza and ATRA for AML and MDS (Table 3, P) gave $42 \%$ positive overall responses.

Other combinations were investigated: a Phase I dose escalation combination trial with epirubicin, 5-FU, and cyclophosphamide ${ }^{106}$ in breast cancer (Table 3, Q), and a Phase I trial ${ }^{107}$ with epirubicin for solid tumors (Table 3, R). The rationale for the combination was to facilitate epirubicin access to DNA to potentiate its strand breaks activity as a topoisomerase II inhibitor. Intrinsic epirubicin toxicity was not exacerbated. Reverse combination was found inadequate by the same group. The same group investigated combination with the topoisomerase I inhibitor karenitecin (KTN) 
Table 3 In vivo HDACi effects from clinical data

\begin{tabular}{|c|c|c|c|c|}
\hline \multicolumn{2}{|l|}{$\begin{array}{l}\text { HDACi (metabolism, } \\
\text { half-life, bioavailability) } \\
\text { and combinations }\end{array}$} & MTD, cancer target, DLTs & \multirow[t]{2}{*}{$\begin{array}{l}\text { Biological analyses } \\
\text { (source) }\end{array}$} & $\begin{array}{l}\text { Remarks or } \\
\text { recommendations }\end{array}$ \\
\hline $\begin{array}{l}\mathrm{PB} \text { converted in vivo to the } \\
\text { active metabolite PA, not }\end{array}$ & A & $\begin{array}{l}\text { Phase II, } 27 \text { g/day, GBM, } \\
\text { common DLTs }\end{array}$ & & $\begin{array}{l}\text { Contradictory } \\
\text { with P450-inducing }\end{array}$ \\
\hline indicated, $78 \%$ at $0.5 \mathrm{mM}$ & B & $\begin{array}{l}300-410 \mathrm{mg} / \mathrm{kg} / \text { day, various } \\
\text { cancers, CNS }\end{array}$ & & $\begin{array}{l}\text { anticonvulsants. } \\
\text { One complete } \\
\text { response for } 5 \text { years }\end{array}$ \\
\hline $\mathrm{PB}+5$-aza & $\mathrm{C}$ & $\begin{array}{l}\text { AML/MDS, skin reaction } \\
\text { (5-aza) }\end{array}$ & $\begin{array}{l}\text { H4 acetylation increased } \\
\text { (not correlated with response) }\end{array}$ & \\
\hline & $\mathrm{D}$ & $\begin{array}{l}25 \mathrm{mg} / \mathrm{m}^{2} / \mathrm{d} \text { SQ d. I-I4, Several } \\
\text { cancers, common DLTs + } \\
\text { confusion, hearing loss, } \\
\text { triglyceridemia and hyperuricema }\end{array}$ & Low DNMT activity & \\
\hline \multirow{2}{*}{$\begin{array}{l}\text { AN-9 } \\
\text { Is converted in vivo to } \\
\text { the active metabolite BA, } \\
\text { half-life }<2 \text { minutes }\end{array}$} & E & $\begin{array}{l}3.3 \mathrm{~g} / \mathrm{m}^{2} / \text { day for the solubility } \\
\text { limits, advanced solid malignancies, } \\
\text { common DLTs + visual complaints }^{\mathrm{a}}\end{array}$ & & \\
\hline & $\mathrm{F}$ & $\begin{array}{l}\text { Phase II refractory NSCLC, } \\
\text { common DLTs and dysgeusia }\end{array}$ & & $\begin{array}{l}\text { Well tolerated, active } \\
\text { alone and usable } \\
\text { for NSCLC with } \\
\text { chemotherapy, I-year } \\
\text { survival around 30\% }\end{array}$ \\
\hline $\begin{array}{l}\text { VPA } \\
\text { Glucuronylation, glutamination, } \\
\text { half-life: } 9-18 \text { hours }\end{array}$ & G & $\begin{array}{l}60 \mathrm{mg} / \mathrm{kg} / \mathrm{d} \text {, refractory advanced } \\
\text { cancer, neurological side effects } \\
(\text { Grade } 3 / 4)\end{array}$ & $\begin{array}{l}\mathrm{H} 3, \mathrm{H} 4 \text { acetylation increased, } \\
\text { HDAC2 decreased (PMBC) }\end{array}$ & \\
\hline \multirow[t]{4}{*}{ VPA+ATRA } & $\mathrm{H}$ & $\begin{array}{l}\text { AML, neurologic and cardiovascular } \\
\text { toxicity }\end{array}$ & HDAC2 decreased (PMBC) & \\
\hline & 1 & MDS and relapsed or refractory AML & $\begin{array}{l}\text { Bone marrow blast count } \\
\text { correlated with response }\end{array}$ & $\begin{array}{l}\text { VPA should be used } \\
\text { alone for low risk } \\
\text { MDS and with other } \\
\text { chemotherapeutics } \\
\text { for high risk MDS }\end{array}$ \\
\hline & J & $\begin{array}{l}\text { Recurrent or refractory AML or } \\
\text { MDS, neurocortical, severe bone } \\
\text { pain (Grade } 3 / 4)\end{array}$ & $\begin{array}{l}\text { No significant blast count } \\
\text { reduction, cytogenetic } \\
\text { analysis of patients } \\
\text { is described }\end{array}$ & $\begin{array}{l}\text { Platelet transfusion } \\
\text { independence should } \\
\text { reduce palliative care } \\
\text { and improve the } \\
\text { quality of life }\end{array}$ \\
\hline & $\mathrm{K}$ & AML & & $\begin{array}{l}\text { Particular response } \\
\text { from patients with } \\
\text { AML-M6 }\end{array}$ \\
\hline $\begin{array}{l}\text { VPA+I3-cis RA or } \\
\text { vitamin D3 }\end{array}$ & $\mathrm{L}$ & MDS or CMML & $\begin{array}{l}\text { No relation between VPA } \\
\text { serum level, } \mathrm{H} 3 \text { acetylation } \\
\text { (PMBC, BMMC) or clinical } \\
\text { response }\end{array}$ & $\begin{array}{l}\text { Near } 50 \% \text { patients } \\
\text { had to end the } \\
\text { treatment }\end{array}$ \\
\hline \multirow[t]{2}{*}{$\mathrm{VPA}+5-\mathrm{azaDc}$} & M & Phase I//II leukemia & $\begin{array}{l}\text { DNA demethylation decreased, } \\
\mathrm{H} 3 \text { and } \mathrm{H} 4 \text { acetylation } \\
\text { increased, pl } 5 \text { reactivation, } \\
\text { p2I cipl not stimulated }\end{array}$ & $\begin{array}{l}\text { Objective responses } \\
\text { rate: } 22 \% \text {, complete } \\
\text { remissions: } 19 \%, \\
\text { safety and efficacy } \\
\text { correlated with } \\
\text { reversal of epigenetics } \\
\text { marks }\end{array}$ \\
\hline & $\mathrm{N}$ & $\begin{array}{l}\text { AML, limited non hematologic } \\
\text { toxicity (5-azaDc), encephalopathy } \\
\text { (VPA) }\end{array}$ & $\begin{array}{l}\text { Correlation with re-expression } \\
\text { of ER mRNA and clinical } \\
\text { response, pI5 promoter } \\
\text { methylation decreased DNA } \\
\text { methylation decreased, DNMTI } \\
\text { decreased, histone acetylation } \\
\text { increased }\end{array}$ & \\
\hline
\end{tabular}


Table 3 (Continued)

\begin{tabular}{|c|c|c|c|c|}
\hline $\begin{array}{l}\text { HDACi (metabolism, } \\
\text { half-life, bioavailability) } \\
\text { and combinations }\end{array}$ & & MTD, cancer target, DLTs & $\begin{array}{l}\text { Biological analyses } \\
\text { (source) }\end{array}$ & $\begin{array}{l}\text { Remarks or } \\
\text { recommendations }\end{array}$ \\
\hline VPA + 5-aza & O & Advanced cancers & $\begin{array}{l}\text { DNA methylation decreased } \\
\text { (not significant), } \mathrm{H} 3 \text { acetylation } \\
\text { increased (PMBC) }\end{array}$ & $\begin{array}{l}\text { Safe at doses up to } \\
75 \mathrm{mg} / \mathrm{m}^{2} \text { for } 5 \text {-aza }\end{array}$ \\
\hline VPA + 5-aza + ATRA & $P$ & $\begin{array}{l}50 \mathrm{mg} / \mathrm{kg} / \mathrm{d} \text { for } 7 \text { days, } A M L \text { and } \\
\text { MDS, neurotoxicity }\end{array}$ & $\begin{array}{l}\text { DNA methylation decreased, } \\
\mathrm{H} 3 \text { and } \mathrm{H} 4 \text { deacetylation } \\
\text { increased, p2I cipl and } \\
\text { PI5 mRNA expression not } \\
\text { associated with clinical } \\
\text { response }\end{array}$ & $\begin{array}{l}\text { Combination safe } \\
\text { with significant } \\
\text { clinical activity }\end{array}$ \\
\hline $\begin{array}{l}\text { VPA + epirubicin } \\
\text { or } 5 \text {-FU or } \\
\text { cyclophosphamide }\end{array}$ & $\mathrm{Q}$ & Breast cancers & $\begin{array}{l}\mathrm{H} 3 \text { and } \mathrm{H} 4 \text { acetylation } \\
\text { increased (PMBC), strong } \\
\text { correlation for HDAC2 } \\
\text { decreased in MCF-7 cells, no } \\
\text { correlation for HDAC6 }\end{array}$ & $\begin{array}{l}\text { Objective responses } \\
\text { for } 64 \%(9 / 15) \text { of the } \\
\text { patients }\end{array}$ \\
\hline VPA + epirubicin & $\mathrm{R}$ & $\begin{array}{l}\text { Solid tumors, confusion, } \\
\text { hallucinations, hearing loss and } \\
\text { dizziness (due to VPA half-life) }\end{array}$ & $\begin{array}{l}48 \text { hours exposure VPA for } \\
\text { chromatin decondensation } \\
\text { prior to epirubicin exposure. } \\
\text { Histone acetylation increased } \\
\text { (PBMN) }\end{array}$ & $\begin{array}{l}\text { Responses were } \\
\text { obtained for } \\
\text { anthracycline-resistant } \\
\text { cancers (breast, } \\
\text { cervical and NSCLC). }\end{array}$ \\
\hline $\mathrm{VPA}+\mathrm{KTN}$ & $S$ & $\begin{array}{l}\text { Melanoma, no VPA/KTN synergistic } \\
\text { toxicity }\end{array}$ & $\begin{array}{l}\mathrm{H} 3 \text { and } \mathrm{H} 4 \text { acetylation } \\
\text { increased (PMBC, apparent } \\
\text { plateau for } 60 \mathrm{mg} / \mathrm{kg} / \text { day VPA) }\end{array}$ & $\begin{array}{l}\text { Potential use in } \\
\text { randomized trials } \\
\text { where topoisomerase I } \\
\text { inhibitors are } \\
\text { involved }\end{array}$ \\
\hline $\begin{array}{l}\text { VPA + dazacarbine }+ \\
\text { interferon- } \alpha\end{array}$ & $\mathrm{T}$ & $\begin{array}{l}\text { Advanced inoperable or metastatic } \\
\text { melanoma, high doses VPA } \\
\text { side effects }\end{array}$ & $\begin{array}{l}\text { Histone acetylation increased } \\
\text { (PMBC) with adjusted VPA } \\
\text { doses. }\end{array}$ & $\begin{array}{l}\text { Modification of } \\
\text { the schedule for } \\
\text { further evaluation of } \\
\text { VPA with chemo- } \\
\text { immunotherapy }\end{array}$ \\
\hline VPA Mg salt & $U$ & $\begin{array}{l}\text { Cervical cancer, depressed level of } \\
\text { consciousness }\end{array}$ & $\begin{array}{l}\mathrm{H} 3 \text { and } \mathrm{H} 4 \text { acetylation } \\
\text { increased (PMBC and tumors). }\end{array}$ & \\
\hline VPA Mg salt + hydralazine & $\mathrm{V}$ & $\begin{array}{l}\text { Chemotherapy resistant refractory } \\
\text { solid tumors, hematologic toxicity }\end{array}$ & $\begin{array}{l}\text { DNA methylation decreased, } \\
\text { histone deacetylase activity } \\
\text { decreased, promoter } \\
\text { methylation decreased for } \\
\text { RAR- } \alpha \text { and DPK. I09I genes } \\
\text { upregulated, } 89 \text { genes } \\
\text { downregulated. }\end{array}$ & $\begin{array}{l}\text { Patients from } \\
\text { cisplatin, carboplatin, } \\
\text { paclitaxel, vinorelbine, } \\
\text { gemcitabine, } \\
\text { pemetrexed, } \\
\text { topotecan, } \\
\text { doxorubicin, } \\
\text { cyclophosphamide, } \\
\text { and anastrozole } \\
\text { treatments. } \\
\text { Supports epigenetic- } \\
\text { driven tumor-cell } \\
\text { chemoresistance } \\
\text { hypothesis. }\end{array}$ \\
\hline \multirow[t]{2}{*}{$\begin{array}{l}\text { Vorinostat, glucuronylated, } \\
\beta \text {-oxidized, half-life }<2 \text { hours, } \\
43 \% \text { oral bioavailability }\end{array}$} & W & $\begin{array}{l}\text { Solid tumors and hematological } \\
\text { malignancies, leukcopenia, } \\
\text { thrombocytopenia, respiratory } \\
\text { distress (Grade } 3 / 4 \text { ) }\end{array}$ & $\begin{array}{l}\text { Histones acetylation } \\
\text { increased }(v)\end{array}$ & \\
\hline & $x$ & Mesothelioma, common ${ }^{\mathrm{b}} \mathrm{DLTs}$. & & $\begin{array}{l}\text { A randomized Phase III } \\
\text { study can be } \\
\text { proposed for patients } \\
\text { already treated } \\
\text { unsuccessfully with } \\
\text { pemetrexed }\end{array}$ \\
\hline
\end{tabular}


Table 3 (Continued)

\begin{tabular}{|c|c|c|c|c|}
\hline \multicolumn{2}{|l|}{$\begin{array}{l}\text { HDACi (metabolism, } \\
\text { half-life, bioavailability) } \\
\text { and combinations }\end{array}$} & \multirow{2}{*}{$\begin{array}{l}\text { MTD, cancer target, DLTs } \\
\text { Hematologic malignancies and solid, } \\
\text { common DLTs + anorexia }\end{array}$} & \multirow{2}{*}{$\begin{array}{l}\begin{array}{l}\text { Biological analyses } \\
\text { (source) }\end{array} \\
\text { Histone acetylation (PMBC, } 200 \text { to } \\
600 \mathrm{mg} \text { ). }\end{array}$} & \multirow{2}{*}{$\begin{array}{l}\text { Remarks or } \\
\text { recommendations } \\
\text { Safe when } \\
\text { administered } \\
\text { chronically, broad } \\
\text { range of antitumor } \\
\text { activity. }\end{array}$} \\
\hline & $Y$ & & & \\
\hline & Z & $\begin{array}{l}\text { Advanced leukemias and MDS (AML, } \\
\text { CLL, MDS, ALL, CML), common } \\
\text { DLTs (Grade 3/4) }\end{array}$ & $\begin{array}{l}\text { Incomplete blood count } \\
\text { recovery (AML), histone } \\
\text { acetylation increased at } \\
\text { all doses }\end{array}$ & $\begin{array}{l}\text { None of the } \\
\text { responding patients } \\
\text { have a specific } \\
\text { mRNA signature for } \\
\text { antioxidant genes } \\
\text { to be used as a } \\
\text { biomarker for further } \\
\text { studies. }\end{array}$ \\
\hline & AA & $\begin{array}{l}\text { Recurrent or persistent epithelial } \\
\text { ovarian or primary peritoneal } \\
\text { carcinoma platinum-resistant/ } \\
\text { refractory, common Grade } 3 \\
\text { DLTs + leucopoenia and } \\
\text { neutropenia (Grade 4). }\end{array}$ & & $\begin{array}{l}\text { SAHA is well } \\
\text { tolerated but had } \\
\text { minimal activity as a } \\
\text { single agent }\end{array}$ \\
\hline & $A C$ & $\begin{array}{l}\text { Measurable, relapsed or refractory } \\
\text { breast cancer or NSCLC or } \\
\text { colorectal cancer, common DLTs } \\
\text { (300-400 mg) No DLTs at } 200 \mathrm{mg} \text {. } \\
\text { Recurrent and/or metastatic head } \\
\text { and neck tumors, thrombocytopenia, } \\
\text { anorexia, and dehydration }\end{array}$ & & $\begin{array}{l}\text { The limited patient } \\
\text { exposure was not } \\
\text { sufficient to assess } \\
\text { SAHA efficacy. }\end{array}$ \\
\hline & $A D$ & $\begin{array}{l}\text { GBM, nonhematologic, and } \\
\text { hematologic toxicities (Grade 3). }\end{array}$ & $\begin{array}{l}\mathrm{H} 2 \mathrm{~B}, \mathrm{H} 4 \text { and } \mathrm{H} 3 \text { acetylation } \\
\text { increased. Upregulation of } \\
\text { E-cadherin. }\end{array}$ & $\begin{array}{l}\text { Enzyme-inducing } \\
\text { anticonvulsants } \\
\text { gave lower SAHA } \\
\text { concentrations, well } \\
\text { tolerated, modest } \\
\text { activity. }\end{array}$ \\
\hline & $\mathrm{AE}$ & $\begin{array}{l}\text { Metastatic radioiodine-refractory } \\
\text { thyroid carcinoma, common DLTs } \\
\text { (Grade 3), pneumonia, severe } \\
\text { thrombocytopenia }\end{array}$ & $\begin{array}{l}\mathrm{Tg}(\mathrm{DTC}) \text { and calcitonin (MTC) } \\
\text { are not convenient biomarkers. }\end{array}$ & $\begin{array}{l}\text { Lack of therapeutic } \\
\text { effect }\end{array}$ \\
\hline $\begin{array}{l}\text { Vorinostat }+ \text { carboplatin } \\
\text { and paclitaxel }\end{array}$ & $\mathrm{AF}$ & $\begin{array}{l}\text { Advanced solid malignancies, } \\
\text { common DLTs + emesis (Grade 3), } \\
\text { neutropenia (Grade 4) }\end{array}$ & $\begin{array}{l}\text { SAHA metabolite 4-anilino- } \\
\text { 4-oxobutanoic acid used } \\
\text { as a marker to monitor for } \\
\text { adherence to SAHA therapy. }\end{array}$ & $\begin{array}{l}\text { Combinations } \\
\text { well tolerated and } \\
\text { increased SAHA half- } \\
\text { life, paclitaxel PKs not } \\
\text { altered }\end{array}$ \\
\hline \multirow[t]{3}{*}{$\begin{array}{l}\text { Belinostat, half-life } \\
\mathrm{I}-2 \text { hours }\end{array}$} & AG & $\begin{array}{l}1000 \mathrm{mg} / \mathrm{m}^{2} / \text { day, refractory solid } \\
\text { tumors, common DLTs + atrial } \\
\text { fibrillation }\end{array}$ & $\begin{array}{l}\mathrm{H} 4 \text { acetylation (PMBC), IL-6 } \\
\text { expression levels proposed as } \\
\text { a marker for HDACi toxicity }{ }^{209}\end{array}$ & $\begin{array}{l}50 \% \text { of the patients } \\
\text { achieve stable disease }\end{array}$ \\
\hline & $\mathrm{AH}$ & $\begin{array}{l}1000 \mathrm{mg} / \mathrm{m}^{2} / \text { day, heavily pre-treated } \\
\text { patients with advanced hematological } \\
\text { neoplasia, common DLTs }\end{array}$ & $\begin{array}{l}\text { Histone acetylation increased } \\
\text { (PMBC) up to } 24 \text { hours post } \\
\text { injection. }\end{array}$ & $\begin{array}{l}\text { No bone marrow } \\
\text { toxicity as a } \\
\text { parameter for } \\
\text { combination } \\
\text { therapies. }\end{array}$ \\
\hline & $\mathrm{Al}$ & $\begin{array}{l}\text { Relapsed malignant pleural } \\
\text { mesothelioma, common DLTs }\end{array}$ & & $\begin{array}{l}\text { No objective } \\
\text { responses. One } \\
\text { death from cardiac } \\
\text { arrhythmia, possibly } \\
\text { related to therapy. }\end{array}$ \\
\hline
\end{tabular}


Table 3 (Continued)

\begin{tabular}{|c|c|c|c|c|}
\hline \multirow[t]{2}{*}{$\begin{array}{l}\text { HDACi (metabolism, } \\
\text { half-life, bioavailability) } \\
\text { and combinations } \\
\end{array}$} & & MTD, cancer target, DLTs & $\begin{array}{l}\text { Biological analyses } \\
\text { (source) }\end{array}$ & $\begin{array}{l}\text { Remarks or } \\
\text { recommendations }\end{array}$ \\
\hline & AJ & $\begin{array}{l}\text { Resistant micro papillary ovarian } \\
\text { tumors (LMP) and epithelial ovarian } \\
\text { cancer, common DLTs + thrombosis } \\
\text { (Grade 3) }\end{array}$ & $\begin{array}{l}\mathrm{H} 3 \text { and } \mathrm{H} 4 \text { acetylation } \\
\text { increased (PMBC and tumor } \\
\text { tissue). Disease. }\end{array}$ & $\begin{array}{l}\text { Diseases with poor } \\
\text { prognostic and } \\
\text { scarce studies, well } \\
\text { tolerated, promising } \\
\text { results for LMP }\end{array}$ \\
\hline Givinostat & AK & $\begin{array}{l}\text { Relapsed/refractory HL, } \\
\text { thrombocytopenia and prolongation } \\
\text { of QTc interval }\end{array}$ & $\begin{array}{l}\text { QTc interval in some cases } \\
\text { prompting drug discontinuation }\end{array}$ & \\
\hline $\begin{array}{l}\text { Givinostat, alone or + } \\
\text { dexamethasone }\end{array}$ & $\mathrm{AL}$ & $\begin{array}{l}\text { Twice daily } 100 \mathrm{mg} / 4 \text { days/week, } \\
12 \text { weeks, MM, one death, cardiac } \\
\text { toxicities (givinostat) }\end{array}$ & $\begin{array}{l}\text { Already treated patients, one } \\
\text { death was reported }\end{array}$ & $\begin{array}{l}\text { Unlikely to play } \\
\text { a significant role } \\
\text { for MM, other } \\
\text { combination may be } \\
\text { investigated }\end{array}$ \\
\hline $\begin{array}{l}\text { Givinostat }+ \\
\text { meclorethamine }\end{array}$ & AM & Relapsed/refractory HL & $\begin{array}{l}\text { TARC decrease in serum as } \\
\text { an easy-to-detect biomarker } \\
\text { predicting response to therapy, } \\
\text { five ( } 15 \%) \text { complete remissions } \\
\text { and eight (23\%) partial } \\
\text { remissions, median survival } \\
28 \text { months, projected 2-year } \\
\text { survival } 52 \%\end{array}$ & $\begin{array}{l}\text { I5\% complete } \\
\text { remissions, median } \\
\text { survival at } 28 \text { months, } \\
\text { projected } 2-y e a r \\
\text { survival of } 52 \% .\end{array}$ \\
\hline \multirow[t]{2}{*}{$\begin{array}{l}\text { Panobinostat, half-life } \\
\text { II-16 hours }\end{array}$} & AN & $\begin{array}{l}<11.5 \mathrm{mg} / \mathrm{m}^{2}, \mathrm{AML}, \mathrm{ALL}, \mathrm{MDS}, \\
\text { common minor DLTs, and cardiac } \\
\text { toxicity (Grade } 3 \text { ) }\end{array}$ & $\begin{array}{l}\text { H3 acetylation increased } \\
\text { (B-cells (CDI9+) and blasts } \\
(\mathrm{CD} 34+)), \mathrm{H} 2 \mathrm{~B} \text { acetylation } \\
\text { increased (CDI9+ and CD34+ } \\
\text { cells), apoptosis increased for } \\
\text { CD34+. }\end{array}$ & \\
\hline & $\mathrm{AO}$ & $\begin{array}{l}\text { CTCL, classical DLTs at } 20 \mathrm{mg}+ \\
\text { thrombocytopenia, toxic at } 30 \mathrm{mg}\end{array}$ & $\begin{array}{l}\text { RNA profiling: } 23 \text { genes } \\
\text { regulated in all patients. } \mathrm{H} 3 \\
\text { acetylation increased (PMBC } \\
\text { and tumors) }\end{array}$ & Complete remission \\
\hline Panobinostat + docetaxel & $\mathrm{AP}$ & $\begin{array}{l}\text { Castration resistant prostate } \\
\text { cancer, neutropenia and dyspnea } \\
\text { (Grade 3) }\end{array}$ & $\begin{array}{l}\text { Progressive disease despite } \\
\text { histone acetylation increased } \\
\text { (PMBC) in first regimen, PSA } \\
\text { decreased in second regimen }\end{array}$ & $\begin{array}{l}\text { Intravenous } \\
\text { administration } \\
\text { suggested for further } \\
\text { investigations }\end{array}$ \\
\hline \multirow[t]{2}{*}{$\begin{array}{l}\text { Dacinostat, half-life } \\
9-18 \text { hours }\end{array}$} & $\mathrm{AQ}$ & $\begin{array}{l}\text { Advanced solid tumors, common } \\
\text { DLTs and transaminitis, fibrillation, } \\
\text { raised serum creatinine, and } \\
\text { hyperbilirubinemia. }\end{array}$ & $\begin{array}{l}\text { Histones acetylation increased } \\
\text { (PMBC), HSP90210 inhibition } \\
\text { measured by HSP72 levels } \\
\text { increased; } \mathrm{H} 3 \text { and } \mathrm{H} 4 \\
\text { acetylation increased for } \\
>24 \text { hours, Hsp70 increased } \\
\text { and c-Raf decreased. }\end{array}$ & $\begin{array}{l}\text { Nonhistone-mediated } \\
\text { effects requires } \\
\text { further study }\end{array}$ \\
\hline & $A R$ & $\begin{array}{l}\text { ALL, AML, CLL, CML, MDS, dose } \\
\text { dependant DLTs: cerebral bleed } \\
\text { secondary to thrombocytopenia } \\
\text { (CLL), reversible hyperbilirubinemia }\end{array}$ & $\begin{array}{l}\text { Histone acetylation increased } \\
>24 \text { hours, nonlinear PK }\end{array}$ & $\begin{array}{l}\text { Rematologic } \\
\text { improvement } \\
\text { observed, mean } \\
\text { terminal half-lives } \\
9-18 \text { hours (maximum } \\
\text { plasma concentrations } \\
1.5 \text { hours after the } \\
\text { beginning of infusion). }\end{array}$ \\
\hline $\begin{array}{l}\text { PCI- } 2478 \text { I half-life } \\
5.9 \text { hours, oral } \\
\text { bioavailability } 34 \%\end{array}$ & AS & $\begin{array}{l}\text { Refractory advanced solid tumors, } \\
\text { common and cardiac DLTs }\end{array}$ & $\begin{array}{l}\text { Acetylation levels increased at } \\
\text { I.5 hours post dose sustained } \\
\geq 24 \text { hours (oral). }\end{array}$ & \\
\hline
\end{tabular}

(Continued) 
Table 3 (Continued)

\begin{tabular}{|c|c|c|c|c|}
\hline $\begin{array}{l}\text { HDACi (metabolism, } \\
\text { half-life, bioavailability) } \\
\text { and combinations }\end{array}$ & & MTD, cancer target, DLTs & $\begin{array}{l}\text { Biological analyses } \\
\text { (source) }\end{array}$ & $\begin{array}{l}\text { Remarks or } \\
\text { recommendations }\end{array}$ \\
\hline \multirow[t]{3}{*}{$\begin{array}{l}\text { Entinostat, half-life } \\
34-50 \text { hours, } \\
\text { highly protein bound, } \\
\text { apparent linear PKs }\end{array}$} & AT & $\begin{array}{l}10 \mathrm{mg} / \mathrm{m}^{2} \text {, advanced solid tumors } \\
\text { or lymphoma, common DLTs }\end{array}$ & HDAC inhibition (PMBC) & $\begin{array}{l}\text { More frequent } \\
\text { dosing proposed } \\
\text { for evaluation from } \\
\text { linear PKs data, } \\
\text { elimination half-life } \\
\text { dose-independent } \\
\text { clearance }\end{array}$ \\
\hline & $\mathrm{AU}$ & $\begin{array}{l}\text { Refractory solid tumors and human } \\
\text { lymphoid malignancies, reversible } \\
\text { DLTs (Grade 3, hypophosphatemia, } \\
\text { hyponatremia, and hypoalbuminemia) }\end{array}$ & $\begin{array}{l}\text { Protein acetylation increased } \\
\text { (by multivariable flow } \\
\text { cytometry in PMBC ( } \mathrm{T} \text { cells } \\
\text { (most robust response), B cells, } \\
\text { and monocytes)) }\end{array}$ & $\begin{array}{l}\text { Well tolerated } \\
\text { administered weekly } \\
\text { with food }\end{array}$ \\
\hline & AV & $\begin{array}{l}8 \mathrm{mg} / \mathrm{m}^{2} \text { weekly for } 4 \text { weeks every } \\
6 \text { weeks, AML, infections and } \\
\text { neurologic toxicity }\end{array}$ & $\begin{array}{l}\text { Protein and histone } \mathrm{H} 3 / \mathrm{H} 4 \\
\text { acetylation increased (PMBC, } \\
\text { BMMC), p2I expression } \\
\text { increased, and caspase- } 3 \\
\text { activation (BMMC) }\end{array}$ & $\begin{array}{l}\text { Detailed cytogenetic } \\
\text { analysis performed } \\
\text { on patients, inherent } \\
\text { resistance to MS- } 275 \\
\text { for advanced leukemia } \\
\text { with complex } \\
\text { karyotype }\end{array}$ \\
\hline
\end{tabular}

High degree of interpatient variations in $\mathrm{H} 3$ and $\mathrm{H} 4$ acetylation increased (PMBC) ymphomas, hypophosphatemia, and asthenia

AX Metastatic melanoma, toxicity mild to moderate

Mocetinostat, half-life 6.7-I2.2 hours

$60 \mathrm{mg} / \mathrm{m}^{2}, \mathrm{AML}, \mathrm{MDS}, \mathrm{ALL}$, and CML, common DLTs (Grade 3)

BA

Advanced leukemias or MDS, common DLTs

Mocetinostat continued $85 \mathrm{mg}$ dose exhibited meaningful activity, HL

BC

FL, common Grade 3 DLTs + anorexia, thrombocytopenia, pericardial serious adverse event

Tacedinaline BD
$\mathrm{H} 3$ acetylation increased (PWBC, measured with the BOC-Lys( $\varepsilon-A c)-A M C$ fluorophore), IL-6 induction Histone acetylation increased (PWBC, measured with the BOC-Lys( $\varepsilon-A c)-A M C$ fluorophore).

HDAC inhibition (PMBC)

TARC levels correlated with clinical response
$8 \mathrm{mg} / \mathrm{m}^{2} /$ day for 8 weeks, repeated after a 2-week drug-free interval, solid tumors, common DLTs + thrombocytopenia, anemia, mucositis
Patients with

pretreated metastatic, melanoma, treatment well tolerated, no objective responses, median time-toprogression was 5I-56 days Interpatient variability improved with low $\mathrm{pH}$ beverages

Three complete bone marrow response, cytogenetic analysis of patients not correlated with responses, safe and anti-leukemia activity for advanced leukemia Four patients with stable disease Two complete responses (10\%), six partial responses (29\%) No clear relationships with schedules, cardiac diseases, pathologies, and biomarkers such as HDAC activity. 
Table 3 (Continued)

\begin{tabular}{|c|c|c|c|c|}
\hline $\begin{array}{l}\text { HDACi (metabolism, } \\
\text { half-life, bioavailability) } \\
\text { and combinations }\end{array}$ & & MTD, cancer target, DLTs & $\begin{array}{l}\text { Biological analyses } \\
\text { (source) }\end{array}$ & $\begin{array}{l}\text { Remarks or } \\
\text { recommendations }\end{array}$ \\
\hline Tacedinaline + capecitabine & BE & $\begin{array}{l}6 \mathrm{mg} / \mathrm{m}^{2} \text { Tacedinaline and } 2000 \\
\mathrm{mg} / \mathrm{m}^{2} / \text { day capecitabine, for } 2 \text { weeks } \\
\text { of a 3-week cycle, advanced solid } \\
\text { malignancy, DLT was } \\
\text { thrombocytopenia }\end{array}$ & & $\begin{array}{l}\text { No overlapping } \\
\text { toxicity }\end{array}$ \\
\hline Tacedinaline + gemcitabine & $\mathrm{BF}$ & $\begin{array}{l}\text { Advanced pancreatic cancers, } \\
\text { neutropenia, and thrombocytopenia }\end{array}$ & & $\begin{array}{l}\text { Combination does not } \\
\text { improve treatment }\end{array}$ \\
\hline \multirow[t]{8}{*}{$\begin{array}{l}\text { Depsipeptide, natural } \\
\text { disulfide prodrug, } \\
\text { half-life } 8 \text { hours }\end{array}$} & BG & $\begin{array}{l}13.3 \mathrm{mg} / \mathrm{m}^{2}, \text { incurable cancers, } \\
\text { common DLTs + thrombocytopenia, } \\
\text { and fatigue. }\end{array}$ & $\begin{array}{l}\text { Histone acetylation increased } \\
\text { (MNPB), PC3 cell cycle arrest } \\
\text { induction, MDR-I induced, } \\
\text { functional PgP. }\end{array}$ & 4-hour infusion safe \\
\hline & $\mathrm{BH}$ & $\begin{array}{l}17.8 \mathrm{mg} / \mathrm{m}^{2} / 4 \mathrm{~h} \text {, advanced or } \\
\text { refractory neoplasms, common } \\
\mathrm{DLTs}+\text { grade- } 4 \text { thrombocytopenia } \\
\text { and cardiac arrhythmia. }\end{array}$ & $\begin{array}{l}\text { Histone acetylation increased } \\
\text { (PMBC), MDR-I induced. }\end{array}$ & $\begin{array}{l}\text { Continuous cardiac } \\
\text { monitoring, one } \\
\text { partial response, } \\
472.6 \mathrm{ng} / \mathrm{mL} \text { mean } \\
\text { maximum plasma } \\
\text { concentration at MTD }\end{array}$ \\
\hline & $\mathrm{BI}$ & CLL, AML, common DLTs & $\begin{array}{l}\text { HDAC inhibition increased, } \\
\text { histone and } \mathrm{p} 2 \mathrm{I} \text { promoter } \\
\mathrm{H} 4 \text { acetylation increased, } \\
\mathrm{P} 2 \mathrm{I} \text { protein and IDI0 } \\
\text { antigen expression increased, } \\
\text { acetylation increased for } \\
\mathrm{H} 4 \mathrm{~K} 5, \mathrm{KI} 2, \mathrm{~K} 8, \mathrm{KI} 6 \text {, and } \\
\mathrm{H} 3 \mathrm{~K} 9, \mathrm{KI} 4\end{array}$ & \\
\hline & BJ & $\begin{array}{l}17 \mathrm{mg} / \mathrm{m}^{2} \text {, refractory or recurrent } \\
\text { solid tumors, reversible, } \\
\text { asymptomatic T-wave inversions, } \\
\text { transient asymptomatic sick sinus } \\
\text { syndrome, and hypocalcemia }\end{array}$ & $\begin{array}{l}\text { HDAC inhibition increased } \\
(\mathrm{PMBC})\end{array}$ & $\begin{array}{l}\text { Depsipeptide is well } \\
\text { tolerated but no } \\
\text { objective responses }\end{array}$ \\
\hline & BK & $\begin{array}{l}\text { MDS and AML, common DLTs } \\
\text { (Grade } 3 / 4 \text { asymptomatic } \\
\text { hypophosphatemia) }\end{array}$ & $\begin{array}{l}\text { Apoptosis increased and } \\
\text { changes in myeloid maturation } \\
\text { marker expression. No changes } \\
\text { in } \mathrm{H} 3 \text { and } \mathrm{H} 4 \text { acetylation, } \\
\mathrm{CD} 34 / \mathrm{Cl} 3 \text { stimulation. }\end{array}$ & $\begin{array}{l}\text { One complete } \\
\text { remission (AML) } \\
\text { acceptable toxicity, } \\
\text { limited activity in } \\
\text { unselected AML/MDS } \\
\text { patients }\end{array}$ \\
\hline & BL & $\begin{array}{l}\text { Refractory renal cell cancer, } \\
\text { cardiac side effects }\end{array}$ & & $\begin{array}{l}\text { One complete } \\
\text { response but not } \\
\text { active enough in } \\
\text { this population, one } \\
\text { sudden death }\end{array}$ \\
\hline & BM & $\begin{array}{l}\text { Metastatic neuroendocrine tumors, } \\
\text { common DLTs, serious cardiac } \\
\text { adverse events }\end{array}$ & & One sudden death \\
\hline & $\mathrm{BN}$ & Lung cancers & $\begin{array}{l}\mathrm{H} 4 \text { acetylation increased, } \mathrm{p} 2 \mathrm{I} \\
\text { expression increased. } 16 \text { gene } \\
\text { expressions stimulated } \geq 2 \text {-fold, } \\
>1000 \text { genes repressed } \\
\geq 2 \text {-fold. }\end{array}$ & $\begin{array}{l}\text { Depsipeptide not } \\
\text { appropriate but } \\
\text { renormalize lung } \\
\text { cancer cells to normal } \\
\text { bronchial epithelia }\end{array}$ \\
\hline
\end{tabular}

Notes: aResulted from formaldehyde released after AN-9 metabolism; ' ${ }^{\circ}$ Common DLTs are considered to be fatigue, nausea, vomiting.

Abbreviaions: 5-aza, 5-aza-cytidine; 5-azaDc, 5-aza-2'-deoxycytidine; 5-FU, 5-fluorouracil; I3-cis-RA, I3-cis-retinoic acid; ALL, acute lymphoblastic leukemia; AMC, 7-amino4-methylcoumarin; AML, acute myeloid leukemia; AN-9, pivaloyloxymethyl butyrate 9; ATRA, all-trans retinoic acid; BA, butyric acid; BMMC, bone marrow mononuclear cell; CLL, chronic lymphocytic leukemia; CML, chronic myelocytic leukemia; CMML, chronic myelomonocytic leukemia; CNS, central nervous system; CTCL, cutaneous T-cell lymphoma; DLT, dose-limiting toxicity; DNMT, DNA methyltransferases; DTC, differentiated thyroid carcinoma; ER, estrogen receptor; FL, follicular lymphoma; GBM, glioblastoma multiform; HDAC, histone deacetylase; HDACi, HDAC inhibitor; HL, Hodgkin lymphoma; IL-6, interleukin-6; KTN, karenitecin; LMP, low malignant potential; MDS, myelodysplastic syndrome; MM, multiple myeloma; MTC, medullary thyroid cancer; MTD, maximum tolerated dose; NSCLC, nonsmall cell lung cancer; PA, phenylacetate; PB, phenylbutyrate; PgP, P-glycoprotein; PK, pharmacokinetic; PMBC, peripheral mononuclear blood cell; PSA, prostate specific antigen; PWBC, peripheral white blood cell; QTc, QT interval corrected for heart rate; RAR- $\alpha$, retinoic acid receptor- $\alpha$; SAHA, suberoylanilide hydroxamicacid; TARC, thymus and activation regulated chemokine; $\mathrm{Tg}$, thyroglobulin; VPA, valproic acid. 
(Table 3, S) for treating melanoma with both Phase I/II trials. ${ }^{108}$ No VPA/KTN synergistic toxicity was observed. The best response was disease stabilization. VPA plus chemoimmunotherapy was investigated in a Phase II study ${ }^{109}$ for advanced inoperable or metastatic melanoma (Table 3, T), HDACi having been previously found to have a tumorigenic potential in melanoma. ${ }^{110}$ Some patients then received dacarbazine plus interferon- $\alpha$ with VPA.

The magnesium salt of VPA has been tested in phase $\mathrm{I}^{111}$ for cervical cancer (squamous and in adenocarcinoma) and Phase II $^{112}$ clinical trials. In the Phase I study (Table 3, U), VPA was given per os, and the authors emphasized the requirement for new endpoint trials based on biomarker analysis ${ }^{113,114}$ with, in this particular case, H3 and H4 acetylation and in vivo HDAC inhibition detection. The Phase II study was conducted with hydralazine, a demethylating agent, ${ }^{115}$ (Table 3, V) to overcome chemotherapy resistance in refractory solid tumors (cervix, breast, ovarian, and others). Partial responses and disease stabilization were the best responses.

\section{Vorinostat}

Vorinostat (suberoylanilide hydroxamicacid [SAHA], Zolinza $^{\circledR}$ ) has probably been the most studied compound in clinical trials on several cancer types. SAHA induces differentiation, ${ }^{116}$ growth arrest, ${ }^{117}$ or apoptosis at micromolar concentrations. Vorinostat is an unselective zinc-binding ${ }^{118}$ hydroxamic-acid-type inhibitor of HDAC1, 2, 3, 6, and 8. In glioma cells, SAHA induced expression of DR5, TNF $\alpha$, p21Waf1, and p27Kip1 and reduced expression of CDK2, CDK4, cyclin D1, and cyclin D2. ${ }^{119}$ SAHA can induce thyroid cancer cell death by caspase-mediated pathways, ${ }^{120}$ and induces G1 and G2-M arrest and apoptosis in several types of breast cancer cell lines, ${ }^{121,122}$ NSCLC,${ }^{123}$ and prostate cancer cells. ${ }^{124}$ It potentiates the activity of other molecules like Paclitaxel in ovarian cancers. ${ }^{125}$

Phase I trials have been described for both oral and I.V administrations. Escalating I.V. administration ${ }^{126}$ in solid tumors and hematological malignancies (Table 3, W) gave hypotension for one schedule. In mesothelioma, with I.V. or oral formulations, ${ }^{127}$ the best responses were partial (Table 3, X). An oral formulation for hematologic malignancies (Hodgkin's and others) (Table 3, Y) and solid tumors (mainly mesothelioma, prostate, urothelial, thyroid, and renal) ${ }^{128}$ gave one complete response while others were incomplete. Oral twice- or thrice-daily administrations in advanced leukemias and MDS (AML, CLL [chronic lymphocytic leukemia], MDS, ALL and CML [chronic myelocytic leukemia]) (Table 3, Z) ${ }^{129}$ gave two complete responses and two complete responses with incomplete blood-count recovery (all with AML treated at/below maximum tolerated dose [MTD]).

Phase II clinical trials were mainly proposed with oral formulations. A multi-institutional trial ${ }^{130}$ in women with recurrent or persistent epithelial ovarian (Table 3, AA) or primary peritoneal carcinoma platinum-resistant/refractory gave one partial response. Another multicenter open-label oral trial ${ }^{131}$ investigated measurable, relapsed, or refractory breast cancer, NSCLC, or colorectal cancer (Table 3, AB). Disease stabilization was observed in eight patients. SAHA is tolerated at $200 \mathrm{mg}$ only, in a daily oral schedule for 14 days-3 weeks. In recurrent and/or metastatic head and neck cancer (400 mg every day) (Table AC) $)^{132}$ no confirmed responses have been observed. In patients with metastatic breast cancer, ${ }^{133}$ there were no complete or partial responses, and the heterogeneity of the recruited patients did not allow production of significant statistical results. Eight patients were positive for estrogen and/or progesterone receptors, four had amplified CerB-2. Fatigue, nausea, diarrhea, and lymphopenia were the most frequent clinically significant adverse effects. In $\mathrm{GBM}^{134}$ (Table $3 \mathrm{AD}$ ), an oral dose of $200 \mathrm{mg}$ followed by a 7-day rest period showed that SAHA monotherapy is well tolerated with modest single-agent activity. Although HDACi were shown to induce cell death and sensitize cells to cytotoxic chemotherapy in thyroid cancer cell lines, Woyach et $\mathrm{al}^{135}$ described the lack of therapeutic effect of SAHA in patients with metastatic radioiodine-refractory thyroid carcinoma in a Phase II study (Table 3, AE). A Phase II oral combination therapy was proposed with carboplatin (I.V.) and Paclitaxel (I.V.) for advanced solid malignancies ${ }^{136}$ (Table 3, AF). Eleven partial responses occurred and seven disease stabilizations. The regimen requires drug-drug interaction to be determined. Encouraging results were obtained in patients with previously untreated NSCLC.

\section{Belinostat}

Belinostat (PXD101) is a recent hydroxamic acid HDACi that has growth-inhibitory and pro-apoptotic activity in several cancer types at submicromolar concentrations, ${ }^{137,138}$ and that has been investigated in ovarian cancers. ${ }^{139}$ It down regulates thymidilate synthase, vascular endothelial growth factor (VEGF), aurora kinase, and epidermal growth factor receptor (EGFR), and up regulates cyclin A. It has been used in combination. A gene expression-signature profiling has been reported for Belinostat. ${ }^{140}$ According to publications ${ }^{141}$ PKs gave a general 1-2-hour half-life. In early trials, DNA fragmentation increased with a combination of 5-FU in 
HCT116 colon cancer cells in vitro and in both HT-29 and HCT116 in xenograft models, ${ }^{142}$ and also a poly(ADP-ribose) polymerase (PARP) cleavage and down regulation of thymidylate synthase expression in HCT116. Improved tumor reduction was obtained in vivo with mouse HT29 and HCT116 xenograft models compared with single compounds, validating a rationale for the clinical schedule.

In Phase I treatment of refractory solid tumors by I.V. administration (Table $3, \mathrm{AG})^{143}$ the caspase-dependent cleavage of cytokeratin-18 was determined to measure the level of apoptosis. ${ }^{144}$ Heavily pre-treated patients with advanced hematological neoplasia ${ }^{145}$ (Table 3, AH) were also treated. In Phase II trials, investigations of I.V. administration of relapsed malignant pleural mesothelioma ${ }^{146}$ (Table 3, AI) indicated that combination strategies or alternate dosing schedules might be necessary. In resistant micro-papillary ovarian tumors (low malignant potential [LMP]) and epithelial ovarian cancers (EOC) (Table 3, AJ), ${ }^{147}$ a Phase II trial with Belinostat gave partial responses or stable diseases for LMP, and stabilized diseases for EOC.

\section{Givinostat}

Givinostat (ITF2357) belongs to the hydroxamic acid family of HDACi which is very similar to SAHA. It inhibits IL-6 and VEGF production in stromal cells. ${ }^{148}$

Two Phase II studies were described for relapsed/refractory Hodgkin lymphoma (HL) (Table 3, AK). A first oral one, gave stable diseases by computed tomography (CT) scan that have been associated with a significant reduction in fluorodeoxyglucose-positron emission tomography scan uptake. ${ }^{149}$ Galli et al ${ }^{150}$ developed a Phase II multicenter trial in 19 heavily treated patients that were relapsing from progressive multiple myeloma (MM) (Table 3, AL). The best responses were disease stabilization. This regimen appears as unlikely to play a significant role for advanced $\mathrm{MM}$, and other combinations with currently used drugs should be investigated. A combination with the alkylating agent mechlorethamine ${ }^{151}$ (Table 3, AM) was investigated in relapsed/refractory HL.

\section{Panobinostat}

Panobisnostat (LBH589) is a hydroxamic acid HDACi, which has demonstrated anti-angiogenic and anti-proliferative activities in human prostate carcinoma cell PC-3 xenografts in vivo, inducing $\mathrm{H} 3$ and tubulin acetylation ${ }^{152}$ in human umbilical vascular endothelial cells (HUVEC), which corresponded to G2-M cell cycle arrest and inhibition of HUVEC cell proliferation and viability. Non cytotoxic concentrations of Panobinostat inhibited endothelial tube formation, matrigel invasion, AKT, extracellular signal-regulated kinase 1/2 phosphorylation, and chemokine receptor CXCR4 expression. Association with anti-VEGF therapies should be considered. Prince et al have discussed preclinical data on Panobinostat and emerging data from Phase I and II studies in cancer patients. ${ }^{153}$

A Phase I study in refractory hematologic malignancies (AML, ALL, and MDS) (Table 3, AN) ${ }^{154}$ with I.V. administration appeared convenient to obtain anti-leukemic and biological effects. In cutaneous T-cell lymphoma (CTCL) ${ }^{47}$ with oral formulation (Table 3, AO), the responses ranged from disease stabilization to complete remission, showing the potential of this molecule in CTCL. In combination with Docetaxe $^{155}$ (Table 3, AP), a microtubule interacting agent for castration-resistant prostate cancer, Panobinostat inhibited LnCAP androgen receptor positive prostate cancer cell proliferation, potentiated by Docetaxel. Single or combined treatments were administered with oral Panobinostat.

\section{Dacinostat}

Dacinostat (NVPLAQ824, LAQ) is a hydroxamic acid derivative similar to Panobinostat. ${ }^{156}$ It showed anti-neoplastic activity and can activate genes that produce cell cycle arrest. It acetylates hsp90, inducing proteosomal degradation of BcrAbl and HER-2. Combination of Dacinostat with 5-azaDc ${ }^{157}$ in human MDA-MB-231 and MCF-7 breast carcinoma cells showed a synergic anti-neoplastic activity for the MDA-MB231. For the MCF-7 tumor cells, simultaneous 5-azaDc and Dacinostat administration were antagonistic, unseen when used in a sequential schedule (5-azaDc first). This is probably due to interference in the S-phase of Dacinostat since 5 -azaDc is a S-phase specific interfering molecule. Dacinostat appeared to be well tolerated in clinical trials. Phase I investigations ${ }^{158}$ in advanced solid tumors included measure of HSP72 levels and was consistent with HSP90 inhibition (Table 3, AQ). Another group ${ }^{159}$ reported the same results with increased expression of Hsp70 and decreased c-Raf levels. The biological importance of these non histones mediated effects requires further study. I.V. administration for ALL, AML, CLL, CML ${ }^{160}$ (Table 3, AR) in blast crisis or advanced MDS gave some stable diseases.

\section{$\mathrm{PCl}-2478 \mathrm{I}$}

PCI-24781 is a broad-spectrum hydroxamic acid-based HDACi. PCI-24781 reverses drug resistance in four multidrug resistant sarcoma cell lines and synergizes with chemotherapeutic agents to enhance caspase-3/7 activity. ${ }^{161}$ 
In refractory advanced solid tumors ${ }^{162}$ (Table 3, AS), I.V. administration followed by dose escalation was well tolerated. Electro cardiac monitoring revealed grade $\leq 1 \mathrm{QTcF}(\mathrm{QT}$ interval corrected for heart rate using Fridericia's formula) prolongation and asymptomatic nonspecific ST and T wave changes leading to discontinuation.

\section{Entinostat}

Entinostat (MS-275, SNX-275) is a benzamide HDACi, which promotes expression of genes involved in growth arrest and differentiation, like $\mathrm{p} 21$ and the maturation marker: gelsolin, ${ }^{163}$ inducing caspase-dependant apoptosis in CLL B-cells, ${ }^{164}$ p21CIP1/WAF1 differentiation or apoptosis in human leukemia cells, ${ }^{165}$ and also tissue growth factor (TGF)BII receptor expression in human breast cancer. ${ }^{166}$ Reported half-life in animals is about 1 hour, and speciesvariable protein binding was reported. ${ }^{167}$ Half-life in human plasma was higher than in animals, which is supposedly to be linked to protein binding, as Entinostat was found to be $80 \%$ bound. ${ }^{167}$

Phase I study in advanced solid tumors or lymphoma by oral route ${ }^{168}$ (Table 3, AT) was reasonably well tolerated. In refractory solid tumors and human lymphoid malignancies ${ }^{169}$ (Table 3, AU), drug exposure increases linearly with dose. In $\mathrm{AML}^{170}$ (Table 3, AV), results showed that Entinostat effectively inhibits HDAC in vivo in patients with AML and should be further tested, preferably in patients with less-advanced disease. Several protocols were designed for patients with advanced solid malignancies and lymphomas ${ }^{171}$ (Table 3, AW). PKs revealed dose-dependent and dose-proportional increases. Responses were partial remissions and prolonged disease stabilization. In a Phase II study for metastatic melanoma (Table 3, AX) with low efficacy treatment, ${ }^{172}$ long-term tumor stabilizations have been observed, but no objective responses was assessed.

\section{Mocetinostat}

Mocetinostat (MGCD0103) ${ }^{173}$ is a benzamide selective class I/IV HDACi (1, 2, 3, and 11). It inhibits neoplastic growth in multiple human tumor xenograft models including colon (HCT116, SW48, and Colo205), NSCLC (A549), prostate (DU145), pancreatic (PANC1), and vulval epidermal (A431) cancer models and does not interact with the potassium voltage-gated channel, subfamily $\mathrm{H}$ (eag-related), member 2 (HERG) channel. Gene expression induced by Mocetinostat is modest compared with other hydroxamic HDACi. ${ }^{174}$

In patients with advanced solid tumors ${ }^{175}$ (Table 3, AY), a phase I study gave disease stabilization as the best response.
IL-6 induction related to HDACi activity has been postulated but not confirmed. At the tested doses, Mocetinostat appeared tolerable and exhibited favorable PK and PD profiles, as well as evidence of target inhibition in surrogate tissues. Cytogenetically analyzed patients with AML, MDS, ALL, and $\mathrm{CML}^{176}$ (Table 3, AZ) were treated orally. A total of 18 of the 29 patients had abnormal cytogenetics. PK analyses indicated rapid absorption of Mocetinostat. Several administration schedules have been proposed for advanced leukemias or $\mathrm{MDS}^{177}$ (Table 3, BA). A Phase II study for HL ${ }^{178}$ (Table 3, BB) demonstrated significant anti-tumor activity in relapsed/refractory post-transplant HL. For 437 patients ${ }^{179}$ (Table 3, BC), partial responses were obtained. Extended studies are ongoing.

\section{Tacedinaline}

The long-known molecule Tacedinaline (CI-994) is a benzamide HDACi similar to MS-275 ${ }^{180}$ with anti-tumor activities in HCT-8 colon carcinoma. ${ }^{181}$ Following Tacedinaline administration, inhibition of both histone deacetylation and cellular proliferation at the G1 to $\mathrm{S}$ transition phase of the cell cycle are observed.

Oral administration with food intake for solid tumors ${ }^{182}$ (Table 3, BD) did not affect the rate or extent of the drug absorption. Best responses were partial or stable diseases. Advanced solid malignancies (mainly colorectal, pancreatic and mesothelioma) were treated in combination with Capecitabine $^{183}$ (Table 3, BE), an FDA-approved compound used to treat a variety of cancer. Three treatment protocols were implemented. A combination Phase II study with Gemcitabine $^{184}$ for advanced pancreatic carcinoma (Table 3, BF) gave no improvement.

\section{Depsipeptide}

Depsipeptide (Romidepsin, FK228, FR901228) is a cyclic tetrapeptide isolated from Chromobacterium violaceum which has demonstrated anti tumor activities (A549 lung adenocarcinoma, MCF-7 and ZR-75-1 breast adenocarcinoma, and LOX IMVI melanoma cell lines) and is postulated as a Pg-p substrate. ${ }^{185,186}$ It is considered as a natural HDACi prodrug, as its disulfide bond is reduced in vivo to give the active species ${ }^{40}$ and is the only reported sulfur-based HDACi used in clinical trials. It received FDA approval for cutaneous T-cell lymphoma in 2009. Romidepsin induces growth arrest and apoptosis in lung cancer cells. ${ }^{187}$ Romidepsin induces p21-dependent G1 arrest and p21-independent G2 arrest ${ }^{188}$ by downregulating cyclin D1 and upregulating cyclin E. ${ }^{189} \mathrm{It}$ inhibits c-Myc and Fas ligand expression, ${ }^{190}$ modulates p53, 
ErbB1, HER2, and Raf-1 expression in lung cancer cells, ${ }^{191}$ increases $\mathrm{p} 21$, phosphorylation of $\mathrm{Bcl} 2$, and apoptosis in human breast cancer cells, ${ }^{192}$ increases expression of a $\mathrm{NaI}$ symporter in thyroid carcinoma cells for possible resensitization of radio resistant thyroid cancer, ${ }^{193}$ and activates the caspase 8-mediated apoptosis and down regulates the c-FLIP protein. ${ }^{194}$ Sequential treatments with 5-azaDc facilitates cancer cell recognition by $\mathrm{T}$ lymphocytes specific for cancer/testis antigen $1 \mathrm{~B}$ (NY-ESO-1) as a possible option for immunotherapy ${ }^{195}$ or induces tissue factor pathway inhibitor (TFPI)-2 expression in cancer cells. ${ }^{196}$ Initial cardiac toxicity was resolved by convenient administration schedules but cardiac monitoring is most of the time implemented during clinical investigations. Concentrations studies in CLL and AML have correlated apoptosis induction and HDAC inhibition. Combination of Romidepsin and DNA demethylating agents is potentiated in ETO positive leukemia cells. ${ }^{197}$ A gene signature specific for Romidepsin sensitivity has been reported. ${ }^{198}$ Due to the recent approval of Romidepsin in CTCL, all early published clinical trials for this disease are not discussed. ${ }^{199,200}$ Romidepsin induced MDR-1 gene expression in several cancer cell lines.

A Phase I study in advanced, incurable cancers ${ }^{201}$ (Table 3, BG) indicated that further clinical trials are warranted. Used for advanced or refractory neoplasms ${ }^{202}$ (Table 3, BH), elimination half-life was 8.1 hours. In CCL and $\mathrm{AML}^{203}$ (Table 3, BI), intravenous treatment gave no responses. Romidepsin effectively inhibits HDAC in vivo in patients with CLL and AML, but future studies should examine alternative administration routes. In refractory or recurrent solid tumors ${ }^{204}$ (Table 3, BJ), DLTs were not associated with changes in troponin levels or evidence of ventricular dysfunction, transient asymptomatic sick sinus syndrome and hypocalcemia. For MDS and AML ${ }^{205}$ (Table 3, BK), intravenous administration gave no significant cardiac toxicity. Romidepsin therapy can be administered with acceptable short-term toxicity. Gastrointestinal symptoms and fatigue seemed to be treatment-limiting after multiple cycles. Phase II performed on refractory renal cell cancer ${ }^{206}$ (Table 3, BL), I.V., gave classical but serious toxicities. Two patients developed a prolonged QT interval, one patient developed grade 3 atrial fibrillation and tachycardia, and there was one sudden death. In metastatic neuroendocrine tumors $^{207}$ (Table 3, BM), adverse events were ventricular tachycardia and prolonged QT, possibly resulting in a sudden death, terminating the study prematurely. Romidepsin has serious cardiac adverse events, and risks need to be comprehensively evaluated. In lung cancers (NSCLC and SCLC)
(Table 3, BN), ${ }^{208}$ Romidepsin was not appropriate. This study presented an in depth gene expression profiling.

\section{Conclusion}

A number of clinical trials have been completed and many others are ongoing using HDACi as single agents and in combination with radiotherapy and/or chemotherapy for the treatment of various hematological and solid malignancies with some promising early results. Vorinostat is the most established HDACi, and was approved in October 2006 by the FDA for the treatment of advanced forms of cutaneous T-cell lymphoma that have failed multiple other systemic treatment options. Significant single agent activity for Romidepsin has also been demonstrated in peripheral cutaneous T-cell lymphoma, and encouraging results have also been seen in HL with Mocetinostat. From the trials conducted, it is also clear that a major clinical advantage is that HDACi are well tolerated in the majority of patients. The future of HDACi lies in designing rational combination therapies. The sequence of drug administration may be of paramount importance to avoid antagonistic effects. The possibility of drug-drug interactions and enhanced toxicities is to be considered. HDACi are also evaluated in non cancerous pathologies like AIDS, graft versus host diseases, and polycythemia verae. Very soon, SIRT activators could find therapeutic applications in lung interstitial diseases. Like for the kinase inhibitors, more selective third generation HDACi are sought, yet specific tests remain to be designed to screen for bioactivity in vitro and in vivo. ${ }^{211}$

\section{Acknowledgments}

This work was supported in part by the COST action TD0905 Epigenetics: bench to bedside and by the Agence Nationale de la Recherche (France).

\section{Disclosure}

The authors report no conflicts of interest in this work.

\section{References}

1. Choudhuri S, Cui Y, Klaassen CD. Molecular targets of epigenetic regulation and effectors of environmental influences. Toxicol Appl Pharmacol. 2010;245(3):378-393.

2. Santos-Rosa H, Caldas C. Chromatin modifier enzymes, the histone code and cancer. Eur J Cancer. 2005;41(16):2381-2402.

3. Oliver SS, Denu JM. Dynamic interplay between histone H3 modifications and protein interpreters: emerging evidence for a "histone language". Chembiochem. 2011;12(2):299-307.

4. Zee BM, Levin RS, Dimaggio PA, et al. Global turnover of histone post-translational modifications and variants in human cells. Epigenetics Chromatin. 2010;3:22-33.

5. Dekker F, Haisma HJ. Histone acetyl transferases as emerging drug targets. Drug Discovery Today. 2009;14(19/20):942-948. 
6. Lim S, Metzger E, Schüle R, et al. Epigenetic regulation of cancer growth by histone demethylases. Int J Cancer. 2010;127(9):1991-1998.

7. Nicholson TB, Chen T, Richard S. The physiological and pathophysiological role of PRMT1-mediated protein arginine methylation. Pharmacol Res. 2009;60(6):466-474.

8. Fackelmayer FO. Protein arginine methyltransferases: guardians of the Arg? Trends Biochem Sci. 2005;30(12):666-671.

9. Tini M, Naeem H, Torchia J. Biochemical analysis of arginine methylation in transcription. Methods Mol Biol. 2009;523:235-247.

10. Spannhoff AT, Hauser R, Heinke W, et al. The emerging therapeutic potential of histone methyltransferase and demethylase inhibitors. ChemMedChem. 2009;4(10):1568-1582.

11. Zhang Y, Xu K, Ni M, et al. Nucleosome dynamics define transcriptional enhancers. Nature Genetics. 2010;42(4):343-347.

12. Copeland RA, Olhava EJ, Scott MP. Targeting epigenetic enzymes for drug discovery. Curr Opin Chem Biol. 2010;14(4):505-510.

13. Jones PA, Baylin SB. The fundamental role of epigenetic events in cancer. Nat Rev Genet. 2002;3(6):415-428.

14. Kriaucionis S, Heintz N. The nuclear DNA base 5-hydroxymethylcytosine is present in purkinje neurons and the brain. Science. 2009;324(5929):929-930.

15. Abdel-Wahab O, Mullally A, Hedvat C, et al. Genetic characterization of TET1, TET2, and TET3 alterations in myeloid malignancies. Blood. 2009;114(1):144-147.

16. Fabbri M, Calin GA. Epigenetics and miRNAs in human cancer. $A d v$ Genet. 2010;70:87-99.

17. Zain J, Kaminetzki D, O'Connor OA. Emerging role of epigenetic therapies in cutaneous T-cell lymphomas. Expert Rev Hematol. 2010;3(2):187-203.

18. Graham JS, Kaye SB, Brown R. The promises and pitfalls of epigenetic therapies in solid tumors. Eur J Cancer. 2009;45(7):1129-1136.

19. Bolden JE, Peart MJ, Johnstone RW. Anticancer activities of histone deacetylase inhibitors. Nat Rev Drug Discov. 2006;5(9): 5769-5784.

20. Haberland M, Montgomery RL, Olson EN. The many roles of histone deacetylases in development and physiology: implications for disease and therapy. Nat Rev Genet. 2009;10(1):32-42.

21. Razidlo DF, Whitney TJ, Casper ME, et al. Histone deacetylase 3 depletion in osteo/chondroprogenitor cells decreases bone density and increases marrow fat. PLoS One. 2010;5(7):e11492.

22. Bhaskara S, Chyla BJ, Amann JM, et al. Deletion of histone deacetylase 3 reveals critical roles in $\mathrm{S}$ phase progression and DNA damage control. Mol Cell. 2008;30(1):61-72.

23. De Zoeten EF, Wang L, Sai H, et al. Inhibition of HDAC9 increases T regulatory cell function and prevents colitis in mice. Gastroenterology. 2010;138(2):583-594.

24. Kotian S, Liyanarachchi S, Zelent A, et al. Histone deacetylases 9 and 10 are required for homologous recombination. $J$ Biol Chem. Epub 2011 Jan 18

25. Kelly G. A review of the sirtuin system, its clinical implications, and the potential role of dietary activators like resveratrol: part 1. Altern Med Rev. 2010;15(3):245-263.

26. Zhang Y, Kwon S, Yamaguchi T, et al. Mice lacking histone deacetylase 6 have hyperacetylated tubulin but are viable and develop normally. Mol Cell Biol. 2008;28(5):1688-1701.

27. Mai A, Altucci L. Epi-drugs to fight cancer: from chemistry to cancer treatment, the road ahead. Int J Biochem Cell Biol. 2009;41(1):199-213.

28. Marks PA, Dokmanovic M. Histone deacetylase inhibitors: discovery and development as anticancer agents. Expert Opin Investig Drugs. 2005;14(12):1497-1511.

29. Bertrand P. Inside HDAC with HDAC inhibitors. Eur J Med Chem. 2010;45(6):2095-2116.

30. Yurek-George A, Cecil AR, Mo AH, et al. The first biologically active synthetic analogues of FK228, the depsipeptide histone deacetylase inhibitor. J Med Chem. 2007;50(23):5720-5726.
31. Khan N, Jeffers M, Kumar S, et al. Determination of the class and isoform selectivity of small-molecule histone deacetylase inhibitors. Biochem J. 2008;409(2):581-589.

32. KrennHrubec K, Marshall BL, Hedglin M, et al. Design and evaluation of 'linkerless' hydroxamic acids as selective HDAC8 inhibitors. Bioorg Med Chem Lett. 2007;17(10):2874-2878.

33. Estiu G, Greenberg E, Harrison CB, et al. Structural origin of selectivity in class II-selective histone deacetylase inhibitors. J Med Chem. 2008; 51(10):2898-2906.

34. Taori K, Paul VJ, Luesch H. Structure and activity of largazole, a potent antiproliferative agent from the Floridian marine cyanobacterium Symploca sp. J Am Chem Soc. 2008;130(6):1806-1807.

35. Huhtiniemi T, Suuronen T, Lahtela-Kakkonen M, et al. Ne-Modified lysine containing inhibitors for SIRT1 and SIRT2. Bioorg Med Chem. 2010;18(15):5616-5625.

36. Huhtiniemi T, Wittekindt C, Laitinen T, et al. Comparative and pharmacophore model for deacetylase SIRT1. J Comput Aided Mol Des. 2006;20(9):589-599.

37. Elaut G, Török G, Vinken M, et al. Major phase I biotransformation pathways of Trichostatin A in rat hepatocytes and in rat and human liver microsomes. Drug Metab Dispos. 2002;30(12):1320-1328.

38. Ebbel EN, Leymarie N, Schiavo S, et al. Identification of phenylbutyrate-generated metabolites in Huntington disease patients using parallel liquid chromatography/electrochemical array/mass spectrometry and off-line tandem mass spectrometry. Analytical Biochem. 2010;399(2):152-161.

39. Parise RA, Holleran JL, Beuner JH, et al. A liquid chromatographyelectrospray ionization tandem mass spectrometric assay for quantitation of the histone deacetylase inhibitor, vorinostat (suberoylanilide hydroxamicacid, SAHA), and its metabolites in human serum. J Chrom B. 2006;840(2):108-115.

40. Du L, Musson DG, Wang AQ. Stability studies of vorinostat and its two metabolites in human plasma, serum and urine. J Pharm Biomed Anal. 2006;42(5):556-564.

41. Furumai R, Matsuyama A, Kobashi N, et al. FK228 (depsipeptide) as a natural prodrug that inhibits class I histone deacetylases. Cancer Res. 2002;62(17):4916-4921.

42. Xiao JJ, Byrd J, Marcucci G, et al. Identification of thiols and glutathione conjugates of depsipeptide FK228 (FR901228), a novel histone protein deacetylase inhibitor, in the blood. Rapid Commun Mass Spectrom. 2003;17(8):757-766.

43. Shiraga T, Tozuka Z, Ishimura R, et al. Identification of cytochrome P450 enzymes involved in the metabolism of FK228, a potent histone deacetylase inhibitor, in human liver microsomes. Biol Pharm Bull. 2005;28(1):124-129.

44. Kim HM, Oh SJ, Park SK, et al. In vitro metabolism of KBH-A40, a novel delta-lactam-based histone deacetylase (HDAC) inhibitor, in human liver microsomes and serum. Xenobiotica. 2008;38(3):281-293.

45. Fonsi M, Fiore F, Jones P, et al. Metabolism-related liabilities of a potent histone deacetylase (HDAC) inhibitor and relevance of the route of administration on its metabolic fate. Xenobiotica. 2009;39(10): $722-737$.

46. Peart MJ, Smyth GK, van Laar RK, et al. Identification and functional significance of genes regulated by structurally different histone deacetylase inhibitors. PNAS. 2005;102(10):3697-3702.

47. Ellis L, Pan Y, Smyth GK, et al. Histone deacetylase inhibitor panobinostat induces clinical responses with associated alterations in gene expression profiles in cutaneous T-cell lymphoma. Clin Cancer Res. 2008;14(14):4500-4510.

48. Kato N, Tanaka J, Sugita J, et al. Regulation of the expression of MHC class I-related chain A, B (MICA, MICB) via chromatin remodeling and its impact on the susceptibility of leukemic cells to the cytotoxicity of NKG2D-expressing cells. Leukemia. 2007;21(10):2103-2108.

49. Vo DD, Prins RM, Begley JL, et al. Enhanced antitumor activity induced by adoptive T-cell transfer and adjunctive use of the histone deacetylase inhibitor LAQ824. Cancer Res. 2009;69(22):8693-8699. 
50. Cameron EE, Bachman KE, Myöhänen S, et al. Synergy of demethylation and histone deacetylase inhibition in the re-expression of genes silenced in cancer. Nat Genet. 1999;21(1):103-107.

51. Appelbaum FR, Baer MR, Carabasi MH, et al. NCCN Practice guidelines for acute myelogenous leukemia. Oncology. 2000;14(11A):53-61.

52. Snykers S, Vinken M, Rogiers V, et al. Differential role of epigenetic modulators in malignant and normal stem cells: a novel tool in preclinical in vitro toxicology and clinical therapy. Arch Toxicol. 2007;81(8): 533-544.

53. Marks PA, Miller T, Richon VM. Histone deacetylases. Curr Opin Pharmacol. 2003;3(4):344-351.

54. DiGiuseppe JA, Weng LJ, Yu KH, et al. Phenylbutyrate-induced G1 arrest and apoptosis in myeloid leukemia cells: structure-function analysis. Leukemia. 1999;13(8):1243-1253.

55. Carducci MA, Nelson JB, Chan-Tack KM, et al. Phenylbutyrate induces apoptosis in human prostate cancer and is more potent than phenylacetate. Clin Cancer Res. 1996;2(2):379-387.

56. Zhang X, Wei L, Yang Y, Yu Q. Sodium 4-phenylbutyrate induces apoptosis of human lung carcinoma cells through activating JNK pathway. J Cell Biochem. 2004;93(4):819-829.

57. Gorospe M, Shack S, Guyton KZ, et al. Up-regulation and functional role of $\mathrm{p} 21 \mathrm{Waf} 1 / \mathrm{Cip} 1$ during growth arrest of human breast carcinoma MCF-7 cells by phenylacetate. Cell Growth Differ. 1996;7(12): 1609-1615.

58. Liu L, Hudgins WR, Miller AC, et al. Transcriptional upregulation of TGF- $\alpha$ by phenylacetate and phenylbuytrate is associated with differentiation of human melanoma cells. Cytokine. 1995;7(5):449-456.

59. Han S, Wada RK, Sidell N. Differentiation of human neuroblastoma by phenylacetate is mediated by peroxisome proliferatoractivated receptor gamma. Cancer Res. 2001;61(10):3998-4002.

60. Carducci MA, Nelson JB, Chan-Tack KM, et al. Phenylbutyrate induces apoptosis in human prostate cancer and is more potent than phenylacetate. Clin Cancer Res. 1996;2(2):379-387.

61. Brusilow SW. Phenylacetylglutamine may replace urea as a vehicle for waste nitrogen excretion. Pediatr Res. 1991;29(2):147-150.

62. Phuphanich S, Baker SD, Grossman SA, et al. Oral sodium phenylbutyrate in patients with recurrent malignant gliomas: a dose escalation and pharmacologic study. Neuro Oncol. 2005;7(2):177-182.

63. Carducci MA, Gilbert J, Bowling MK, et al. A phase I clinical and pharmacological evaluation of sodium phenylbutyrate on an 120-h infusion schedule. Clin Cancer Res. 2001;7(10):3047-3055.

64. Gilbert J, Baker SD, Bowling MK, et al. A phase I dose escalation and bioavailability study of oral sodium phenylbutyrate in patients with refractory solid tumor malignancies. Clin Cancer Res. 2001;7(8) 2292-2300.

65. Camacho LH, Olson J, Tong WP, et al. Phase I dose escalation clinical trial of phenylbutyrate sodium administered twice daily to patients with advanced solid tumors. Invest New Drugs. 2007;25(2):131-138.

66. Gore SD, Weng LJ, Zhai S, et al. Impact of prolonged infusions of the putative differentiating agent sodium phenylbutyrate on myelodysplastic syndromes and acute myeloid leukemia. Clin Cancer Res. 2002;8(4): 963-970.

67. Maslak P, Chanel S, Camacho LH, et al. Pilot study of combination transcriptional modulation therapy with sodium phenylbutyrate and 5 -azacytidine in patients with acute myeloid leukemia or myelodysplastic syndrome. Leukemia. 2006;20(2):212-217.

68. Gilbert J, Baker SD, Donehower R, et al. Methytransferase (MT) activity and gene expression in tumor biopsies from patients enrolled in a Phase I study of the MT inhibitor, 5-azacytidine (5AC), and the histone deacetylase inhibitor, phenylbutyrate (PB), in refractory solid tumors. Proc Am Soc Clin Onc. 2001:87a.

69. Sung MW, Waxman S. Combination of cytotoxicdifferentiation therapy with 5-fluorouracil and phenylbutyrate in patients with advanced colorectal cancer. Anticancer Res. 2007;27(2):995-1001.

70. Rephaeli A, Rabizadeh E, Aviram A, et al. Derivatives of butyric acid as potential anti-neoplastic agents. Int J Cancer. 1991;49(1):66-72.
71. Schwartz B, Avivi-Green C, Polak-Charcon S. Sodium butyrate induces retinoblastoma protein dephosphorylation, $\mathrm{p} 16$ expression and growth arrest of colon cancer cells. Mol Cell Biochem. 1998;188(1-2): $21-30$.

72. Mandal M, Adam L, Kumar R. Redistribution of activated caspase-3 to the nucleus during butyric acid-induced apoptosis. Biochem Biophys Res Commun. 1999;260(3):775-780.

73. Rabizadeh E, Shaklai M, Nudelman A, et al. Rapid alteration of c-myc and c-jun expression in leukemic cells induced to differentiate by a butyric acid prodrug. FEBS Lett. 1993;328(3):225-229.

74. Rabizadeh E, O. Bairey, Aviram A, et al. Doxorubicin and a butyric acid derivative effectively reduce levels of $\mathrm{Bcl}-2$ protein in the cells of chronic lymphocytic leukemia patient. Eur J Haematol. 2001;66(4): 263-271.

75. Patnaik A, Rowinsky EK, Villalona MA, et al. A phase I study of pivaloyloxymethyl butyrate, a prodrug of the differentiating agent butyric acid, in patients with advanced solid malignancies. Clin Cancer Res. 2002;8(7):2142-2148

76. Reid T, Valone F, Lipera W, et al. Phase II trial of the histone deacetylase inhibitor pivaloyloxymethyl butyrate (Pivanex, AN-9) in advanced non-small cell lung cancer. Lung Cancer. 2004;45(3): 381-386.

77. Loscher W. Basic pharmacology of valproate: a review after 35 years of clinical use for the treatment of epilepsy. CNS Drugs. 2002;16(10): 669-694.

78. Perucca E. Pharmacological and therapeutic properties of valproate: a summary after 35 years of clinical experience. CNS Drugs. 2002;16(10): 695-714.

79. Marchion DC, Bicaku E, Daud AI, et al. Valproic acid alters chromatin structure by regulation of chromatin modulation proteins. Cancer Res. 2005;65(9):3815-3822.

80. Jung GA, Yoon JY, Moon BS, et al. Valproic acid induces differentiation and inhibition of proliferation in neural progenitor cells via the beta-catenin-Ras-ERK-p21Cip/WAF1 pathway. BMC Cell Biol. 2008; 9:66-78.

81. Gottlicher M, Minucci S, Zhu J, et al. Valproic acid defines a novel class of HDAC inhibitors inducing differentiation of transformed cells. EMBO J. 2001;20(24):6969-6978.

82. Gurvich N, Tsygankova OM, Meinkoth JL, et al. Histone deacetylase is a target of valproic acid-mediated cellular differentiation. Cancer Res. 2004;64(3):1079-1086.

83. Bacon CL, Gallagher HC, Haughey JC, et al. Antiproliferative action of valproate is associated with aberrant expression and nuclear translocation of cyclin D3 during the C6 glioma G1 phase. J Neurochem. 2002;83(1):12-19.

84. Werling U, Siehler S, Litfin M, et al. Induction of differentiation in F9 cells and activation of peroxisome proliferator-activated receptor delta by valproic acid and its teratogenic derivatives. Mol Pharmacol. 2001;59(5):1269-1276.

85. Kawagoe R, Kawagoe H, Sano K. Valproic acid induces apoptosis in human leukemia cells by stimulating both caspase dependent and -independent apoptotic signaling pathways. Leuk Res. 2002;26(5):495-502.

86. Tang R, Faussat AM, Majdak P, et al. Valproic acid inhibits proliferation and induces apoptosis in acute myeloid leukemia cells expressing P-gp and MRP1. Leukemia. 2004;18(7):1246-1251.

87. Ichiyama T, Okada K, Lipton JM, et al. Sodium valproate inhibits production of TNF- $\alpha$ and IL- 6 and activation of NF-KB. Brain Res. 2000;857(1-2):246-251.

88. Siitonen T, Koistinen P, Savolainen ER. Increase in Ara-C cytotoxicity in the presence of valproate, a histone deacetylase inhibitor, is associated with the concurrent expression of cyclin D1 and p27(Kip 1) in acute myeloblastic leukemia cells. Leuk Res. 2005;29(11):1335-1342.

89. Cimino G, Lo-Coco F, Fenu S, et al. Sequential valproic acid/Alltrans retinoic acid treatment reprograms differentiation in refractory and highrisk acute myeloid leukemia. Cancer Res. 2006;66(17):8903-8911. 
90. Valentini A, Gravina P, Federici G, et al. Valproic acid induces apoptosis, p16INK4A upregulation and sensitization to chemotherapy in human melanoma cells. Cancer Biol Ther. 2007;6(2):185-191.

91. Atmaca A, Al-Batran SE, Maurer A, et al. Valproic acid (VPA) in patients with refractory advanced cancer: a dose escalating Phase I clinical trial. British J Cancer. 2007;97(2):177-182.

92. Bug G, Ritter M, Wassmann B, et al. Clinical trial of valproic acid and all-trans retinoic acid in patients with poor-risk acute myeloid leukemia. Cancer. 2005;104(12):2717-2725.

93. Kuendgen A, Knipp S, Fox F, et al. Results of a Phase 2 study of valproic acid alone or in combination with alltrans retinoic acid in 75 patients with myelodysplastic syndrome and relapsed or refractory acute myeloid leukemia. Ann Hematol. 2005;84(Suppl 1): 61-66.

94. Pilatrino C, Cilloni D, Messa E, et al. Increase in platelet count in older, poor-risk patients with acute myeloid leukemia or myelodysplastic syndrome treated with valproic acid and all-trans retinoic acid. Cancer. 2005;104(1):101-109.

95. Raffoux E, Chaibi P, Dombret H, et al. Valproic acid and all-trans retinoic acid for the treatment of elderly patients with acute myeloid leukemia. Haematologica. 2005;90(7):986-988.

96. Duprez E, Lillehaug JR, Naoe T, et al. cAMP signalling is decisive for recovery of nuclear bodies (PODs) during maturation of RA-resistant $\mathrm{t}(15 ; 17)$ promyelocytic leukemia NB4 cells expressing PML-RAR alpha. Oncogene. 1996;12(11):2451-2459.

97. Kuendgen A, Schmid M, Schlenk R, et al. The histone deacetylase (HDAC) inhibitor valproic acid as monotherapy or in combination with all-trans retinoic acid in patients with acute myeloid leukemia. Cancer. 2006;106(1):112-119.

98. Huang S, Brandt SJ. mSin3A regulates murine erythroleukemia cell differentiation through association with the TAL1 (or SCL) transcription factor. Mol Cell Biol. 2000;20(6):2248-2259.

99. Watamoto K, Towatari M, Ozawa Y, et al. Altered interaction of HDAC5 with GATA-1 during MEL cell differentiation. Oncogene. 2003;22(57):9176-9184.

100. Siitonen T, Timonen T, Juvonen E, et al. Valproic acid combined with 13-cis retinoic acid and 1,25-dihydroxyvitamin D3 in the treatment of patients with myelodysplastic syndromes. Haematologica. 2007;92(8):1119-1122.

101. Santini V, Ferrini PR. Differentiation therapy of myelodysplastic syndromes: fact or fiction? Br J Heamatol. 1998;102(5):1124-1138.

102. Garcia-Manero G, Kantarjian HM, Sanchez-Gonzalez B, et al. Phase $1 / 2$ study of the combination of 5-aza- $2^{\prime}$-deoxycytidine with valproic acid in patients with leukemia. Blood. 2006;108(10):3271-3279.

103. Blum W, Klisovic RB, Hackanson B, et al. Phase I study of decitabine alone or in combination with valproic acid in acute myeloid leukemia. J Clin Oncol. 2007;25(25):3884-3891.

104. Braiteh F, Soriano AO, Garcia-Manero G, et al. Phase I study of epigenetic modulation with 5-azacytidine and valproic acid in patients with advanced cancers. Clin Cancer Res. 2008;14(19): 6296-6301.

105. Soriano AO, Yang H, Faderl S, et al. Safety and clinical activity of the combination of 5-azacytidine, valproic acid, and all-trans retinoic acid in acute myeloid leukemia and myelodysplastic syndrome. Blood. 2007;110(7):2302-2308.

106. Münster P, Marchion D, Bicaku E, et al. Clinical and biological effects of valproic acid as a histone deacetylase inhibitor on tumor and surrogate tissues: Phase I/II trial of valproic acid and epirubicin/FEC. Clin Cancer Res. 2009;15(7):2488-2496.

107. Münster P, Marchion D, Bicaku E, et al. Phase I trial of histone deacetylase inhibition by valproic acid followed by the topoisomerase II inhibitor epirubicin in advanced solid tumors: a clinical and translational study. J Clin Oncology. 2007;25(15):1979-1985.

108. Daud AI, Dawson J, DeConti RC, et al. Potentiation of a topoisomerase I inhibitor, karenitecin, by the histone deacetylase inhibitor valproic acid in melanoma: translational and Phase I/II clinical trial. Clin Cancer Res. 2009;15(7):2479-2489.
109. Rocca A, Minucci S, Tosti G, et al. A Phase I-II study of the histone deacetylase inhibitor valproic acid plus chemoimmunotherapy in patients with advanced melanoma. British J Cancer. 2009;100(1):28-36.

110. Fachetti F, Previdi S, Ballarini M, et al. Modulation of pro- and anti-apoptotic factors in human melanoma cells exposed to histone deacetylase inhibitors. Apoptosis. 2004;9(5):573-582.

111. Chavez-Blanco A, Segura-Pacheco B, Perez-Cardenas E, et al. Histone acetylation and histone deacetylase activity of magnesium valproate in tumor and peripheral blood of patients with cervical cancer. A Phase I study. Mol Cancer. 2005;4(1):22.

112. Candelaria M, Gallardo-Rincon D, Arce C, et al. A Phase II study of epigenetic therapy with hydralazine and magnesium valproate to overcome chemotherapy resistance in refractory solid tumors. Ann Oncol. 2007;18(9):1529-1538.

113. Parulekar WR, Einsenhauer EA. Novel endpoints and design of early clinical trials. Annal Oncol. 2002;13(Suppl 4):139-143.

114. Hunsberger S, Rubinstein LV, Dancey J, et al. Dose escalation trial designs based on a molecularly targeted endpoint. Stat Med. 2005;24(14):2171-2181.

115. Segura-Pacheco B, Perez-Cardenas E, Taja-Chayeb L, et al. Global DNA hypermethylation-associated cancer chemotherapy resistance and its reversion with the demethylating agent hydralazine. J Transl Med. 2006;4:32.

116. Richon VM, Webb Y, Merger R, et al. Second generation hybrid polar compounds are potent inducers of transformed cell differentiation. Proc Natl Acad Sci U S A. 1996;93(12):5705-5708.

117. Butler LM, Agus DB, Scher HL, et al. Suberoylanilide hydroxamic acid, an inhibitor of histone deacetylase, suppresses the growth of prostate cancer cells in vitro and in vivo. Cancer Res. 2000;60(78): 5165-5170.

118. Finnin MS, Donigian JR, Cohen A, et al. Structures of a histone deacetylase homologue bound to the TSA and SAHA inhibitors. Nature. 1999;401(6749):188-193.

119. Yin D, Ong JM, Hu J, et al. Suberoylanilide hydroxamic acid, a histone deacetylase inhibitor: effects on gene expression and growth of glioma cells in vitro and in vivo. Clin Cancer Res. 2007;13(3):1045-1052.

120. Mitsiades CS, Poulaki V, McMullan C, et al. Novel histone deacetylase inhibitors in the treatment of thyroid cancer. Clin Cancer Res. 2005;11(10):3958-3965.

121. Munster PN, Troso-Sandoval T, Rosen N, et al. The histone deacetylase inhibitor suberoylanilide hydroxamic acid induces differentiation of human breast cancer cells. Cancer Res. 2001;61(23): 8492-8497.

122. Bali P, Pranpat M, Swaby R, et al. Activity of suberoylanilide hydroxamic acid against human breast cancer cells with amplification of her-2. Clin Cancer Res. 2005;11(17):6382-6389.

123. Komatsu N, Kawamata N, Takeuchi S, et al. SAHA, a HDAC inhibitor, has profound anti-growth activity against non-small cell lung cancer cells. Oncol Rep. 2006;15(1):187-191.

124. Butler LM, Agus DB, Scher HI, et al. Suberoylanilide hydroxamic acid, an inhibitor of histone deacetylase, suppresses the growth of prostate cancer cells in vitro and in vivo. Cancer Res. 2000;60(18); 5165-5170.

125. Dietrich C, Greenberg VL, Desimone CP, et al. Suberoylanilide hydroxamic acid potentiates paclitaxel-induced apoptosis in ovarian cancer cell lines. Gynecol Oncol. 2006;116(1):126-130.

126. Kelly WK, Richon VM, O'Connor O, et al. Phase I clinical trial of histone deacetylase inhibitor: suberoylanilide hydroxamic acid administered intravenously. Clin Cancer Res. 2003;9:(10 Pt 1): 3578-3588.

127. Krug LM, Curley T, Schwartz L, et al. Potential role of histone deacetylase inhibitors in mesothelioma: clinical experience with suberoylanilide hydroxamic acid. Clin Lung Cancer. 2006;7(4):257-261.

128. Kelly WK, O'Connor OA, Krug LM, et al. Phase I study of an oral histone deacetylase inhibitor, suberoylanilide hydroxamic acid, in patients with advanced cancer. J Clin Oncol. 2005;23(17):3923-3931. 
129. Garcia-Manero G, Yangn H, Bueso-Ramos C, et al. Phase 1 study of the histone deacetylase inhibitor vorinostat (suberoylanilide hydroxamic acid [SAHA]) in patients with advanced leukemias andmyelodysplastic syndromes. Blood. 2008;111(3):1060-1066.

130. Modesitt SC, Sill M, Hoffman JS, et al. A Phase II study of vorinostat in the treatment of persistent or recurrent epithelial ovarian or primary peritoneal carcinoma: a Gynecologic Oncology Group study. Gynecol Oncol. 2008;109(2):182-186.

131. Vansteenkiste J, Van Cutsem E, Dumez H, et al. Early Phase II trial of oral vorinostat in relapsed or refractory breast, colorectal, or nonsmall cell lung cancer. Invest New Drugs. 2008;26(5):483-488.

132. Blumenschein GR Jr, Kies MS, Papadimitrakopoulou VA, et al. Phase II trial of the histone deacetylase inhibitor vorinostat (Zolinza, suberoylanilide hydroxamic acid, SAHA) in patients with recurrent and/or metastatic head and neck cancer. Invest New Drugs. 2008;26(1):81-87.

133. Luu TH, Morgan RJ, Leong L, et al. A phase II trial of vorinostat (suberoylanilide hydroxamic acid) in metastatic breast cancer: a California Cancer Consortium study. Clin Cancer Res. 2008;14(21):7138-7142.

134. Galanis E, Jaeckle KA, Maurer MJ, et al. Phase II trial of vorinostat in recurrent glioblastoma multiforme: a north central cancer treatment group study. J Clin Oncol. 2009;27(12):2052-2058.

135. Woyach JA, Kloos RT, Ringel MD, et al. Lack of therapeutic effect of the histone deacetylase inhibitor vorinostat in patients with metastatic radioiodine-refractory thyroid carcinoma. J Clin Endocrinol Metab. 2009;94(1):164-170.

136. Ramalingam SS, Parise RA, Ramanathan RK, et al. Phase I and pharmacokinetic study of vorinostat, a histone deacetylase inhibitor in combination with carboplatin and paclitaxel for advanced solid malignancies. Clin Cancer Res. 2007;13(12):3605-3610.

137. Plumb JA, Finn PW, Williams RJ, et al. Pharmacodynamic response and inhibition of growth of human tumor xenografts by the novel histone deacetylase inhibitor PXD101. Mol Cancer Ther. 2003;2(8):721-728

138. Gimsing P. Belinostat: a new broad acting antineoplastic histone deacetylase inhibitor. Expert Opin Investig Drugs. 2009;18(4):501-508.

139. Gian X, LaRochelle WJ, Ara G, et al. Activity of PXD101, a histone deacetylase inhibitor, in preclinical ovarian cancer studies. Mol Cancer Ther. 2006;5(8):2086-2095.

140. Monks A, Hose CD, Pezzoli P, et al. Gene expression-signature of belinostat in cell lines is specific for histone deacetylase inhibitor treatment, with a corresponding signature in xenografts. Anticancer Drugs. 2009;20(8):682-692.

141. Warren KE, McCully C, Dvinge H, et al. Plasma and cerebrospinal fluid pharmacokinetics of the histone deacetylase inhibitor, belinostat (PXD101), in non-human primates. Cancer Chemother Pharmacol. 2008;62(3):433-437.

142. Tumber A, Collins LS, Petersen K, et al. The histone deacetylase inhibitor PXD101 synergises with 5-Xuorouracil to inhibit colon cancer cell growth in vitro and in vivo. Cancer Chemother Pharmacol. 2007;60:275-283.

143. Steele NL, Plumb JA, Vidal L, et al. A Phase 1 pharmacokinetic and pharmacodynamic study of the histone deacetylase inhibitor belinostat in patients with advanced solid tumors. Clin Cancer Res. 2008;14(3):804-810.

144. Takada M, Kataoka A, Toi M, et al. A close association between alteration in growth kinetics by neoadjuvant chemotherapy and survival outcome in primary breast cancer. Int J Oncol. 2004;25(2) 397-405.

145. Gimsing P, Hansen M, Knudsen LM, et al. A phase I clinical trial of the histone deacetylase inhibitor belinostat in patients with advanced hematological neoplasia. Eur J Hematol. 2008;81(3):170-176.

146. Ramalingam SS, Belani CP, Ruel C, et al. Phase II study of belinostat (PXD101), a histone deacetylase inhibitor, for second line therapy of advanced malignant pleural mesothelioma. J Thorac Oncol. 2009;4(1):97-101.
147. Mackay HJ, Hirte H, Colgan T, et al. Phase II trial of the histone deacetylase inhibitor belinostat in women with platinum resistant epithelial ovarian cancer and micropapillary (LMP) ovarian tumours. Eur J Cancer. 2010;46(9):1573-1579.

148. Golay J, Cuppini L, Leoni F, et al. The histone deacetylase inhibitor ITF2357 has anti-leukemic activity in vitro and in vivo and inhibits IL-6 and VEGF production by stromal cells. Leukemia. 2007;21(9):1892-1900.

149. Viviani S, Bonfante V, Fasola C, et al. Phase II study of the histonedeacetylase inhibitor ITF2357 in relapsed/refractory Hodgkin's lymphoma patients. J Clin Oncol. 2008;26:abstract 8532.

150. Galli M, Salmoiraghi S, Golay J, et al. A Phase II multiple dose clinical trial of histone deacetylase inhibitor ITF2357 in patients with relapsed or progressive multiple myeloma. Ann Hematol. 2010;89(2):185-190.

151. Carlo-Stella C, Guidetti A, Viviani S, et al. Safety and clinical activity of the histone deacetylase inhibitor givinostat in combination with meclorethamine in relapsed/refractory Hodgkin lymphoma (HL). J Clin Oncol. 2010;28:abstract 3068.

152. Qian DZ, Kato Y, Shabbeer S, et al. Targeting tumor angiogenesis with histone deacetylase inhibitors: the hydroxamic acid derivative LBH589. Clin Cancer Res. 2006;12(2):634-642.

153. Prince HM, Bishton MJ, Johnstone RW. Panobinostat (LBH589): a potent pan-deacetylase inhibitor with promising activity against hematologic and solid tumors. Future Oncol. 2009;5(5):601-612.

154. Giles F, Fischer T, Cortes J, et al. Phase I Study of Intravenous LBH589, a novel cinnamic hydroxamic acid analogue histone deacetylase inhibitor, in patients with refractory hematologic malignancies. Clin Cancer Res. 2006;12(15):4628-4635.

155. Rathkopf D, Wong BY, Ross RW, et al. A Phase I study of oral panobinostat alone and in combination with docetaxel in patients with castration-resistant prostate cancer. Cancer Chemother Pharmacol. 2010;66(1):181-189.

156. Remiszewski SW. The discovery of NVPLAQ824: from concept to clinic. Curr Med Chem. 2003;10(22):2393-2402.

157. Hurtubise A, Momparler RL. Effect of histone deacetylase inhibitor LAQ824 on antineoplastic action of 5-Aza-2-deoxycytidine (decitabine) on human breast carcinoma cells. Cancer Chemother Pharmacol. 2006;58(5):618-625.

158. De Bono JS, Kristeleit R, Tolcher A, et al. Phase I pharmacokinetic and pharmacodynamic study of LAQ824, a hydroxamate histone deacetylase inhibitor with a heat shock protein-90 inhibitory profile, in patients with advanced solid tumors. Clin Cancer Res. 2008;14(20):6663-6673.

159. Kristeleit RS, Tandy D, Atadja P, et al. Effects of the histone deacetylase inhibitor (HDACI) LAQ824 on histone acetylation, Hsp70 and c-Raf in peripheral blood lymphocytes from patients with advanced solid tumours enrolled in a phase I clinical trial. $J$ Clin Oncol. 2004;22:abstract 3023

160. Ottmann OG, Deangelo DJ, Stone RM, et al. A Phase I, pharmacokinetic (PK) and pharmacodynamic (PD) study of a novel histone deacetylase inhibitor LAQ824 in patients with hematologic malignancies. J Clin Oncol. 2004;22:abstract 3024.

161. Choy E, Cao Y, Hornicek F, et al. Effect of histone deacetylase inhibitor (HDACI) PCI-24781 on chemotherapy-induced apoptosis in multidrug-resistant sarcoma cell lines. J Clin Oncol. 2010;28:abstract 10089.

162. Undevia SD, Janisch L, Schilsky RL, et al. Phase I study of the safety, pharmacokinetics (PK) and pharmacodynamics (PD) of the histone deacetylase inhibitor (HDACi) PCI-24781. J Clin Oncol. 2008;26:abstract 14514.

163. Jaboin J, Wild J, Hamidi H, et al. MS-27-275, an inhibitor of histone deacetylase, has marked in vitro and in vivo antitumor activity against pediatric solid tumors. Cancer Res. 2002;62(21):6108-6115.

164. Lucas DM, Davis ME, Parthun MR, et al. The histone deacetylase inhibitor MS-275 induces caspase-dependent apoptosis in B-cell chronic lymphocytic leukemia cells. Leukemia. 2004;18(7):1207-1214. 
165. Rosato RR, Almenara JA, Grant S. The histone deacetylase inhibitor MS-275 promotes differentiation or apoptosis in human leukemia cells through a process regulated by generation of reactive oxygen species and induction of p21CIP1/WAF1 1. Cancer Res. 2003;63(13): 3637-3645.

166. Lee BI, Park SH, Kim JW, et al. MS-275, a histone deacetylase inhibitor, selectively induces transforming growth factor beta type II receptor expression in human breast cancer cells. Cancer Res. 2001;61(3): 931-934.

167. Acharya MR, Sparreboom A, Sausville EA, et al. Interspecies differences in plasma protein binding of MS-275, a novel histone deacetylase inhibitor. Cancer Chemother Pharmacol. 2006;57(3):275-281.

168. Ryan QC, Headlee D, Acharya M, et al. Phase I and pharmacokinetic study of MS-275, a histone deacetylase inhibitor, in patients with advanced and refractory solid tumors or lymphoma. J Clin Oncol. 2005;23(17):3912-3922.

169. Kummar S, Gutierrez M, Gardner ER, et al. Phase I trial of MS-275, a histone deacetylase inhibitor, administered weekly in refractory solid tumors and lymphoid malignancies. Clin Cancer Res. 2007; 13(18 Pt 1):5411-5417.

170. Gojo I, Jiemjit A, Trepel JB, et al. Phase 1 and pharmacologic study of MS-275, a histone deacetylase inhibitor, in adults with refractory and relapsed acute leukemias. Blood. 2007;109(7):2781-2790.

171. Gore L, Rothenberg ML, O'Bryant CL, et al. A phase I and pharmacokinetic study of the oral histone deacetylase inhibitor, MS-275, in patients with refractory solid tumors and lymphomas. Clin Cancer Res. 2008;14(14):4517-4525.

172. Hauschild A, Trefzer U, Garbe C, et al. Multicenter phase II trial of the histone deacetylase inhibitor pyridylmethyl-N-\{4-[(2-aminophenyl)carbamoyl]-benzyl \}-carbamate in pretreated metastatic melanoma. Melanoma Res. 2008;18(4):274-278.

173. Zhou N, Moradei O, Raeppel S, et al. Discovery of N-(2aminophenyl)-4-[(4-pyridin-3-ylpyrimidin-2-ylamino)methyl]benzamide (MGCD0103), an orally active histone deacethylase inhibitor. J Med Chem. 2008;51(14):4072-4075.

174. Fournel M, Bonfils C, Hou Y, et al. MGCD0103, a novel isotypeselective histone deacetylase inhibitor, has broad spectrum antitumor activity in vitro and in vivo. Mol Cancer Ther. 2008;7(4):759-768.

175. Siu LL, Pili R, Duran I, et al. Phase I study of MGCD0103 given as a three-times-per-week oral dose in patients with advanced solid tumors. J Clin Oncol. 2008;26(12):1940-1947.

176. Garcia-Manero G, Assouline S, Cortes J, et al. Phase 1 study of the oral isotype specific histone deacetylase inhibitor MGCD0103 in leukemia. Blood. 2008;112(4):981-989.

177. Lancet JE, Nichols G, Assouline S, et al. A Phase I study of MGCD0103 given as a twice weekly oral dose in patients with advanced leukemias or myelodysplastic syndromes (MDS). J Clin Oncol. 2007; 25:abstract 2516.

178. Bociek RG, Kuruvilla GJ, Pro B, et al. Isotype-selective histone deacetylase (HDAC) inhibitor MGCD0103 demonstrates clinical activity and safety in patients with relapsed/refractory classical Hodgkin Lymphoma (HL). J Clin Oncol. 2008;26:abstract 8507.

179. Martell RE, Younes A, Assouline SE, et al. Phase II study of MGCD0103 in patients with relapsed follicular lymphoma (FL): Study reinitiation and update of clinical efficacy and safety. J Clin Oncol. 2010;28:abstract 8086

180. Berger MR, Bischoff H, Fritschi E, et al. Synthesis, toxicity, and therapeutic efficacy of 4-amino-N-(2-aminophenyl) benzamide: a new compound preferentially active in slowly growing tumors. Cancer Treat Rep. 1985;69(12):1415-1424.

181. Kraker AJ, Mizzen CA, Hartl BG, et al. Modulation of histone acetylation by [4-(acetylamino)-N-(2-amino-phenyl) benzamide] in HCT-8 colon carcinoma. Mol Cancer Ther. 2003;2(4):401-408.

182. Prakash S, Foster BJ, Meyer M, et al. Chronic oral administration of CI-994: a Phase 1 study. Invest New Drugs. 2001;19(1):1-11.
183. Undevia SD, Kindler HL, Janisch L, et al. A Phase I study of the oral combination of CI-994, a putative histone deacetylase inhibitor, and capecitabine. Ann Oncol. 2004;15(11):1705-1711.

184. Richards DA, Boehm KA, Waterhouse DM, et al. Gemcitabine plus CI-994 offers no advantage over gemcitabine alone in the treatment of patients with advanced pancreatic cancer: results of a phase II randomized, double-blind, placebo-controlled, multicenter study. Ann Oncol. 2006;17(7):1096-1102.

185. Ueda H, Manda T, Matsumoto S, et al. FR901228, a novel antitumor bicyclic depsipeptide produced by Chromobacterium violaceum No. 968, III: antitumor activities on experimental tumors in mice. J Antibiot. 1994;47(3):315-323.

186. Ueda H, Nakajima H, Hori Y, et al. FR901228, a novel antitumor bicyclic depsipeptide produced by Chromobacterium violaceum No. 968. I. Taxonomy, fermentation, isolation, physicochemical and biological properties, and antitumor activity. J Antibiot. 1994;47(3):301-310.

187. Yu XD, Wang SY, Chen GA, et al. Apoptosis induced by depsipeptide FK228 coincides with inhibition of survival signaling in lung cancer cells. Cancer J. 2007;13(2):105-113.

188. Sandor V, Robbins AR, Robey R, et al. FR901228 causes mitotic arrest but does not alter microtubule polymerization. Anticancer Drugs. 2000;11(11):445-454

189. Sandor V, Senderowicz A, Mertins S, et al. P21-dependent G(1) arrest with downregulation of cyclin D1 and upregulation of cyclin $\mathrm{E}$ by the histone deacetylase inhibitor FR901228. Br J Cancer. 2000;83(6):817-825.

190. Wang R, Brunner T, Zhang L, et al. Fungal metabolite FR901228 inhibits c-Myc and Fas ligand expression. Oncogene. 1998;17(12):1503-1508.

191. Yu X, Guo ZS, Marcu MG, et al. Modulation of p53, ErbB1, ErbB2, and Raf-1 expression in lung cancer cells by depsipeptide FR901228. J Natl Cancer Inst. 2002;94(7):504-513.

192. Rajgolikar G, Chan KK, Wang HC. Effects of a novel antitumor depsipeptide, FR901228, on human breast cancer cells. Breast Cancer Res Treat. 1998;51(1):29-38.

193. Kitazono M, Robey R, Zhan Z, et al. Low concentrations of the histone deacetylase inhibitor, depsipeptide (FR901228), increase expression of the $\mathrm{Na} / \mathrm{I}$ symporter and iodine accumulation in poorly differentiated thyroid carcinoma cells. J Clin Endocrinol Metab. 2001;86(7):3430-3435.

194. Aron JL, Parthun MR, Marcucci G, et al. Depsipeptide (FR901228) induces histone acetylation and inhibition of histone deacetylase in chronic lymphocytic leukemia cells concurrent with activation of caspase 8-mediated apoptosis and down-regulation of c-FLIP protein. Blood. 2003;102(2):652-658.

195. Weiser TS, Guo ZS, Ohnmacht GA, et al. Sequential 5-aza-2 deoxycytidine-depsipeptide FR901228 treatment induces apoptosis preferentially in cancer cells and facilitates their recognition by cytolytic T lymphocytes specific for NY-ESO-1. J Immunother. 2001;24(2):151-161.

196. Steiner FA, Hong JA, Fischette MR, et al. Sequential 5-Aza 2-deoxycytidine/depsipeptide FK228 treatment induces tissue factor pathway inhibitor 2 (TFPI-2) expression in cancer cells. Oncogene. 2005;24(14):2386-2397.

197. Klisovic MI, Maghraby EA, Parthun MR, et al. Depsipeptide (FR 901228) promotes histone acetylation, gene transcription, apoptosis and its activity is enhanced by DNA methyltransferase inhibitors in AML1/ ETO-positive leukemic cells. Leukemia. 2003;17(2):350-358.

198. Sasakawa Y, Naoe Y, Sogo N, et al. Marker genes to predict sensitivityto FK228, a histone deacetylase inhibitor. Biochem Pharmacol. 2005;69(4):603-616.

199. Piekarz RL, Frye R, Turner M, et al. Phase II multi-institutional trial of the histone deacetylase inhibitor romidepsin as monotherapy for patients with cutaneous T-cell lymphoma. J Clin Oncol. 2009;27(32):5410-5417. 
200. Woo S, Gardner ER, Chen X, et al. Population pharmacokinetics of romidepsin in patients with cutaneous T-cell lymphoma and relapsed peripheral T-cell lymphoma. Clin Cancer Res. 2009;15(4):1496-1503.

201. Marshall JL, Rizvi N, Kauh J, et al. A Phase I trial of depsipeptide (FR901228) in patients with advanced cancer. J Exp Ther Oncol. 2002;2(6):325-332.

202. Sandor V, Bakkes S, Robey RW, et al. Phase I trial of the histone deacetylase inhibitor, depsipeptide (FR901228, NSC 630176), in patients with refractory neoplasms. Clin Cancer Res. 2002;8(3);718-728.

203. Byrd JC, Marcucci G, Parthun MR, et al. A phase 1 and pharmacodynamic study of depsipeptide (FK228) in chronic lymphocytic leukemia and acute myeloid leukemia. Blood. 2005;105(3):959-967.

204. Fouladi M, Furman WL, Chin T, et al. Phase I study of depsipeptide in pediatric patients with refractory solid tumors: a Children's Oncology Group report. J Clin Oncol. 2006;24(22):3678-3685.

205. Klimek VM, Fircanis S, Maslak P, et al. Tolerability, pharmacodynamics, and pharmacokinetics studies of depsipeptide (romidepsin) in patients with acute myelogenous leukemia or advanced myelodysplastic syndromes. Clin Cancer Res. 2008;14(3):826-832.
206. Stadler WM, Margolin K, Ferber S, et al. A Phase II study of depsipeptide in refractory metastatic renal cell cancer. Clin Genitourin Cancer. 2006;5(1):57-60.

207. Shah MH, Binkley P, Chan K, et al. Cardiotoxicity of histone deacetylase inhibitor depsipeptide in patients with metastatic neuroendocrine tumors. Clin Cancer Res. 2006;12(13):3997-4003.

208. Schrump DS, Fischette MR, Nguyen DM, et al. Clinical and molecular responses in lung cancer patients receiving Romidepsin. Clin Cancer Res. 2008;14(1):188-198.

209. Sosman JA, Aronson FR, Sznol M, et al. Concurrent phase I trials of intravenous interleukin 6 in solid tumor patients: reversible doselimiting neurological toxicity. Clin Cancer Res. 1997;3(1):39-46.

210. Maloney A, Workman P. HSP90 as a new therapeutic target for cancer therapy: the story unfolds. Expert Opin Biol Ther. 2002;2(1):3-24.

211. Bantscheff M, Hopf C, Savitski MM, et al. Chemoproteomics profiling of HDAC inhibitors reveals selective targeting of HDAC complexes. Nat Biotechnol. 2011. In press.
Cancer Management and Research

\section{Publish your work in this journal}

Cancer Management and Research is an international, peer-reviewed open access journal focusing on cancer research and the optimal use of preventative and integrated treatment interventions to achieve improved outcomes, enhanced survival and quality of life for the cancer patient The journal welcomes original research, clinical \& epidemiological

\section{Dovepress}

studies, reviews \& evaluations, guidelines, expert opinion \& commentary, case reports \& extended reports. The manuscript management system is completely online and includes a very quick and fair peerreview system, which is all easy to use. Visit http://www.dovepress.com/ testimonials.php to read real quotes from published authors. 